\title{
Budgets of reactive nitrogen, hydrocarbons, and ozone over the Amazon forest during the wet season
}

\section{Citation}

Jacob, Daniel J., and Steven C. Wofsy. 1990. "Budgets of Reactive Nitrogen, Hydrocarbons, and Ozone over the Amazon Forest During the Wet Season." Journal of Geophysical Research 95 (D10): 16737. doi:10.1029/jd095id10p16737.

\section{Published Version}

doi:10.1029/JD095iD10p16737

\section{Permanent link}

http://nrs.harvard.edu/urn-3:HUL.InstRepos:14121836

\section{Terms of Use}

This article was downloaded from Harvard University's DASH repository, and is made available under the terms and conditions applicable to Other Posted Material, as set forth at http:// nrs.harvard.edu/urn-3:HUL.InstRepos:dash.current.terms-of-use\#LAA

\section{Share Your Story}

The Harvard community has made this article openly available.

Please share how this access benefits you. Submit a story.

\section{Accessibility}




\title{
Budgets of Reactive Nitrogen, Hydrocarbons, and Ozone Over the Amazon Forest during the Wet Season
}

\author{
DANIEL J. JACOB AND STEVEN C. WOFSY \\ Department of Earth and Planetary Sciences and Division of Applied Sciences, \\ Harvard University, Cambridge, Massachusetts
}

\begin{abstract}
The atmospheric composition over the Amazon forest during the wet season is simulated with a onedimensional photochemical model for the planetary boundary layer (PBL) extending from the ground to 2000-m alitude. The model is constrained and evaluated using observations from the ABLE $2 B$ field expedition. Results indicate that only $\approx 20 \%$ of NO enitted by soils is exported to the atmosphere above the forest canopy. The balance is deposited to vegetation before leaving the canopy layer. The small $\mathrm{NO}_{x}$ flux that escapes from the canopy is nevertheless sufficient to account for the low NO concentrations observed in the PBL. Decomposition of peroxyacetylnitrate (PAN) supplied from aloft provides only a minor source of $\mathrm{NO}_{x}$ in the PBL, although it could provide the major source of $\mathrm{NO}_{x}$ at higher altitudes. Soil emission can account for only a portion of NO observed over the forest. Organic nitrates of nonbiogenic origin likely account for the balance of $\mathrm{NO}_{y}$. Enhancements of $\mathrm{CO}$ observed in the PBL cannot be explained by oxidation of biogenic hydrocarbons, and appear to reflect direct emission of $\mathrm{CO}$ by the forest ecosystem. Concentrations of $\mathrm{O}_{3}$ in the PBL are regulated largely by transport from aloft and deposition to the canopy, with little net influence from photochemistry. Ozone is photochemically produced immediately above the forest where NO concentrations are relatively high, but is photochemically consumed in the upper portion of the PBL.
\end{abstract}

\section{INTRODUCTION}

The ABLE 2B field expedition [Harriss et al., this issue (a)] has provided a detailed survey of atmospheric composition over the Amazon forest during the wet season. The findings reveal a remarkably pristine atmosphere. Concentrations of NO measured from aircraft were usually less than $10 \mathrm{ppt}$ (A. L. Torres and K. R. Hooks, Nitric oxide measurements over the Amazon Basin: ABLE 2B results, submitted to Journal of Geophysical Research, 1989). Concentrations of $\mathrm{O}_{3}$ at $2000 \mathrm{~m}$ altitude averaged $18 \mathrm{ppb}$ [Browell et al., this issue; Gregory et al., this issue; Kirchhoff et $a l$., this issue], and the mean daytime concentration at canopy top was only $6 \mathrm{ppb}$ [Bakwin et al., this issue (a)]. The atmospheric composition observed during $\mathrm{ABLE} 2 \mathrm{~B}$ reflects influences from photochemical reactions, biosphere-atmosphere exchange, vertical mixing, and long-range transport of pollution. We investigate here these influences, using a one-dimensional (ID) photochemical model for the planetary boundary layer (PBL) extending from the ground to $2000 \mathrm{~m}$. We emphasize factors that regulate the concentrations, transformation rates, and fluxes of hydrocarbons, $\mathrm{CO}$, reactive nitrogen species, and $\mathrm{O}_{3}$.

Previous model studies of atmospheric chemistry over the Amazon Basin have focused on dry season conditions [Crutzen et al., 1985; Jacob and Wofsy, 1988]. A major difference between photochemistry in the wet and dry seasons is that NO concentrations are much lower in the wet season. The background PBL concentrations of NO observed during the ABLE 2A dry season expedition ranged from 10 to $60 \mathrm{ppt}$ [Torres and Buchan, 1988], and values up to $250 \mathrm{ppt}$ were observed in fresh biomass burning plumes [Andreae et al., 1988]. The background NO concentrations in the dry season are sufficiently high to allow significant photochemical production of $\mathrm{O}_{3}$ [Jacob and Wofsy, 1988], and this production is enhanced in biomass burning plumes [Crutzen et al., 1985; Andreae et al., 1988; Kirchhoff et al., 1989]. In the wet season, by contrast, we will see that NO concentrations are so low that photochemistry can represent a net sink for $\mathrm{O}_{3}$.

Copyright 1990 by the American Geophysical Union.

Paper number 90JD00001.

(0148-(1227/90/903D-(30001\$05.000
We have argued previously [Jacob and Wofsy, 1988] that the background NO concentrations observed during the dry season could be explained largely by soil emissions of NO. Soil emissions are 5 times lower in the wet season than in the dry season [Bakwin et al., this issue (b)], consistent with the observed seasonality of NO concentrations. Our model results, discussed below, indicate that only $20 \%$ of $\mathrm{NO}_{x}$ emitted by soil is actually exported to the PBL above the forest; the balance is removed by deposition to vegetation during transport from the ground to the top of the canopy. Nevertheless, we argue that soil emissions can account for most of the NO observed in the PBL during the wet season. We argue further that ventilation of $\mathrm{NO}_{x}$ from the PBL to the free troposphere (above $2000 \mathrm{~m}$ ) is negligible, implying that soil emissions of NO from the Amazon Basin make little contribution to the global atmospheric budget of reactive nitrogen.

Several authors, including Crutzen [1979] and Singh [1987], have proposed that thermal decomposition of peroxyacetylnitrate (PAN) could provide an important source of $\mathrm{NO}_{x}$ in low-NO $\mathrm{NO}_{x}$ atmospheres. In particular, the PAN measurements of Singh et al. [this issue] during ABLE 2B suggest that decomposition of PAN could constitute the principal source of $\mathrm{NO}_{x}$ in the free troposphere over the Amazon Basin. The concentrations of PAN were consistently higher in the free troposphere $(20-125 \mathrm{ppt})$ than in the PBL (5-20 ppt), implying a net downward flux of PAN to the PBL. We find however that this flux supplies only a small source of reactive nitrogen to the PBL as compared to soil emissions of NO. Decomposition of PAN to $\mathrm{NO}_{x}$ in the PBL is inhibited by the abundance of peroxyacetyl radicals $\left(\mathrm{CH}_{3} \mathrm{CO}_{3}\right)$ produced from atmospheric oxidation of isoprene. Despite the low levels of $\mathrm{NO}_{x}$, net conversion of $\mathrm{NO}_{x}$ to PAN can take place at midday when $\mathrm{CH}_{3} \mathrm{CO}_{3}$ levels are maximum.

Photochemical oxidation of $\mathrm{NO}_{x}$ produces $\mathrm{HNO}_{3}$ and organic nitrates in addition to PAN. The total concentration of reactive oxides of nitrogen $\left(\mathrm{NO}_{y}\right)$ measured just above canopy top during ABLE 2B averaged about 450 ppt [Bakwin et al., this issue (a)]. Model results indicate that soil emissions of NO cannot account for the observed $\mathrm{NO}_{y}$ concentrations, and we speculate that organic nitrates of nonbiogenic origin make a major contribution to the observed $\mathrm{NO}_{y}$. Local emissions from Manaus, or long-range tran- 
sport of pollution from eastern Brazil and Africa, could be implicated [Andreae et al., this issue (a); Talbot et al., this issue (a)].

Extremely low $\mathrm{O}_{3}$ concentrations were measured during ABLE 2B [Bakwin et al., this issue (a); Browell et al., this issue; Gregory et al., this issue; Kirchhoff et al., this issue], reflecting the rapid deposition of $\mathrm{O}_{3}$ to the forest canopy [Fan et al., this issue] and the lack of photochemical production in the PBL. Previous model studies have pointed out the potential for vigorous photochemical loss of $\mathrm{O}_{3}$ in low-NO $\mathrm{NO}_{x}$ atmospheres [Fishman et al., 1979; Logan et al., 1981; Liu et al., 1983; Chameides et al., 1987]. These previous studies focused on marine environments, where photochemistry involves principally the oxidation of $\mathrm{CO}$ by $\mathrm{OH}$, producing $\mathrm{HO}_{2}$, and the $\mathrm{O}_{3}$ yieid is largely determined by the relative rates of the $\mathrm{HO}_{2}+\mathrm{NO}$ reaction (producing $\mathrm{O}_{3}$ ) and the $\mathrm{HO}_{2}+\mathrm{O}_{3}$ reaction (consuming $\mathrm{O}_{3}$ ). Different photochemistry is expected over the Amazon forest because of the high concentrations of isoprene. Isoprene provides the principal atmospheric sink for $\mathrm{OH}$ in the PBL [Zimmerman et al., 1988; Jacob and Wofsy, 1988], so that rates for $\mathrm{O}_{3}$ production or loss are determined largely by the fates of the organic peroxy radicals $\left(\mathrm{RO}_{2}\right)$ produced from isoprene oxidation. The $: \mathrm{RO}_{2}$ radicals are largely unreactive with $\mathrm{O}_{3}$ [Atkinson and Lloyd; 1984$]$, in contrast to $\mathrm{HO}_{2}$. As a result we find that the crossover from net $\mathrm{O}_{3}$ production to net loss over the Amazon forest takes place at $\approx 5 \mathrm{ppt} N O$, as compared to $\approx 10 \mathrm{ppt}$ NO in marine atmospheres [Fishman et al., 1979; Chameides et al., 1987]. The low $\mathrm{NO}$ concentration required for $\mathrm{O}_{3}$ production moderates the potential for photochemical loss of $\mathrm{O}_{3}$ over the Amazon forest.

The photochemical model developed for the present study includes a detailed mechanism for photochemistry in low-NO $\mathrm{Na}_{x}$ atmospheres [Lurmann et al., 1986; Jacob and Wofsy, 1988], a 1D simulation of transport within the canopy and in the PBL, and a multilevel resistance-in-series scheme for deposition to vegetation [Shreffler, 1978; Meyers and Baldocchi, 1988]. The model is intended to simulate relatively undisturbed meteorological conditions over the Amazon forest, characterized by a well-defined diurnal cycle of mixed layer growth and decay. Such conditions were observed frequently during ABLE $2 B$ [Browell et al., this issue; Gregory et al., this issue], and were interrupted by occasional very large disturbances [Scala et al., this issue]. The structure of the model is described in section 2. Budgets of $\mathrm{O}_{3}$ and $\mathrm{NO}_{x}$ within the canopy are examined in section 3 . The photochemistry of the PBL is discussed in sections 4-8, with focus on hydrocarbons (section 4), CO (section 5), reactive nitrogen (section 6), odd hydrogen (section 7), and $\mathrm{O}_{3}$ (section 8 ). The sensitivity of model results to hydrocarbon levels is investigated in section 9. Concluding remarks are in section 10 . Model results for sulfur species and organic acids are presented elsewhere [Andreae et al., this issue (a); Talbot et al., this issue (b)]. Sensitivity model studies focusing on the mechanisms for dry deposition to the Amazon forest, the export of biogenic $\mathrm{NO}_{x}$ out of the forest canopy, and the effects of human colonization are presented in Fan et al. [this issue], Jacob and Bakwin [1990], and Keller et al. [1990], respectively.

\section{MODEL DESCRIPTION}

\subsection{Transport}

The model domain is restricted to the vertical, extending from the ground to $2000 \mathrm{~m}$. Some rationale for using a $1 \mathrm{D}$ model is provided by the ABLE $2 \mathrm{~B}$ aircraft observations of $\mathrm{O}_{3}$ and aerosol distributions over the Amazon Basin, which show relatively little horizontal variation even during cross-Basin flights from Manaus to Belem [Browell et al., this issue; Gregory et al., this issue].
Most of the time, the observed vertical distributions of $\mathrm{O}_{3}$ an aerosol below $2000 \mathrm{~m}$ display a well-defined diumal pattem $c$. mixed layer growth and decay [Browell et al., this issue; Gregory et al., this issue], which can be reasonably simulated with a 1D model. We focus our attention here on these relatively undisturbed meteorological conditions. The principal drawback of a iD model is that it cannot simulate the efficient mixing of air to high altitudes that takes place during deep convective events [Chatfield and Delany, 1990]. The rapid redistribution of $\mathrm{O}_{3}$ observed during such events is examined by Scala et al. [this issue] using a 2D model.

The upper boundary of the model domain at $2000 \mathrm{~m}$ is assumed to represent the top of the PBL. The PBL includes an active mixed layer, which grows and decays over the course of the day, and a remnant mixed layer above, which is entrained into the active mixed layer during the morning hours. Observations in the dry season indicate a well-defined PBL, capped at $2500-3000 \mathrm{~m}$ by the semi-permanent trade wind inversion [Kousky and Kagano, 1981; Browell et al., 1988; Gregory et al., 1988]. In the wet season the PBL is not as well defined, because the trade wind inversion is absent, however the vertical distributions of various tracers indicate a marked decrease in surface influences above $2000 \mathrm{~m}$. For example, the average $\mathrm{O}_{3}$ vertical profiles reported by Browell et al. [this issue] show a rapid increase of concentrations with altitude up to 2000 m, reflecting the influence of the surface sink for $\mathrm{O}_{3}$, but little further increase above. Similarly, the aerosol profiles reported by Gregory et al. [this issue] usually show a rapid decline in concentrations above $2000 \mathrm{~m}$.

The vertical distributions of trace species within the $0-2000 \mathrm{~m}$ model domain are resolved with seven grid cells (Figure 1), in-

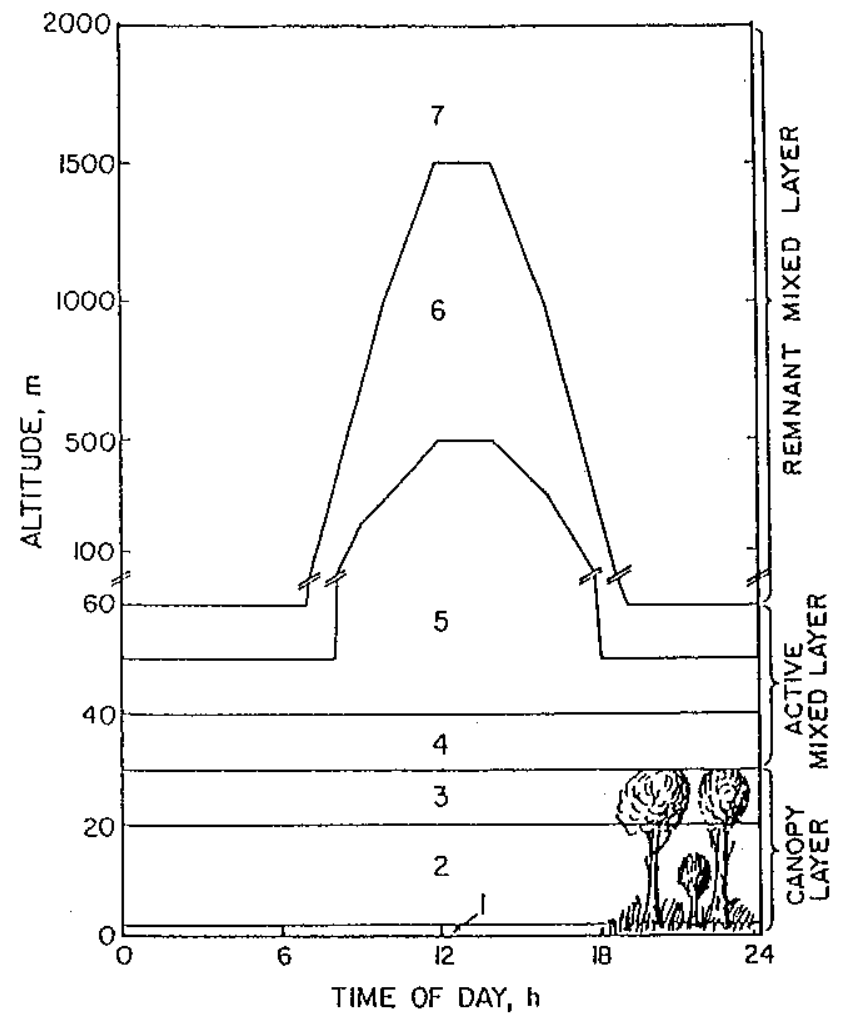

Fig. 1. Vertical structure of the model domain as a function of time of day. The canopy layer (grid cells 1-3) extends from 0 to $30 \mathrm{~m}$, and the PBL (grid cells 4-7) extends from 30 to $2000 \mathrm{~m}$. The tops of grid cells 5 and 6 move with time of day to simulate the growth and decay of the active mixed layer. 
luding three cells in the canopy $(0-30 \mathrm{~m})$ and four cells in the $B \mathrm{~L}$ above the canopy $(30-2000 \mathrm{~m})$. The grid cells are assumed to be individually well-mixed. The subdivision of the canopy layer into three grid cells is intended in part to resolve the observed vertical gradients of ${ }^{222} \mathrm{Rn}, \mathrm{NO}$, and $\mathrm{O}_{3}$ [Trumbore et al., this issue; Bakwin et al., this issue (a)], and in part to resolve the vertical distributions of vegetation density and stomatal resistances [Roberts et al, 1990]. The subdivision of the PBL into four grid cells is intended to distinguish the active mixed layer (grid cells 4-6) from the remnant mixed layer (grid cell 7), and to provide some resolution of vertical transport within the active mixed layer.

Grid cells 4-6 in the model simulate the active mixed layer, which is subject to strong nurbulence in the daytime due to solar heating of the canopy. The depth of the active mixed layer (top of grid cell 6) is specified on the basis of observed vertical distributions of $\mathrm{O}_{3}$ and aerosol [Browell et al., this issue; Gregory et al., this issue]. It varies with time of day as a function of the energy balance at canopy top, peaking at about $1500 \mathrm{~m}$ at midday. As the active mixed layer grows during the morning hours it entrains air from the remnant mixed layer, and the reverse process (stratification) takes place in the late afternoon as the active mixed layer decays [Jacob and Wofsy, 1988]. Entrainment and stratification are simulated using mobile boundaries for grid cells 5-7 (Figure 1), and transfering air between adjacent grid cells as the boundaries move up and down with time of day.

Simulation of turbulent motions above the Amazon forest is complicated. Most of the turbulent energy at canopy height is carried by eddies of size 50-100 m [Fitzjarrald et al., 1988], significantly larger than expected for mechanically generated turbulence. These eddies are likely generated in the active mixed layer, and standard micrometeorological formulations for the turbulent diffusivity $\left(K_{z}\right)$ are probably inapplicable. We choose instead to model turbulent transport by using empirical exchange velocities constrained with observed concentrations and vertical fluxes of $\mathrm{O}_{3},{ }^{222} \mathrm{Rn}$, and $\mathrm{CO}_{2}$. The turbulent mass fluxes are computed as follows:

$$
F_{i, k}=V_{k}\left(C_{i, k}-C_{i, k+1}\right) N_{k}
$$

where $F_{i, k}$ (molecules $\mathrm{cm}^{-2} \mathrm{~s}^{-1}$ ) is the flux of species i from cell $\mathrm{k}$ to cell $k+1, V_{k}$ is the exchange velocity $\left(\mathrm{cm} \mathrm{s}^{-1}\right)$ between cells $k$ and $k+1, C_{i, k}$ is the mixing ratio (v/v) of species $i$ in cell $k$, and $N_{k}$ is the air density (molecules $\mathrm{cm}^{-3}$ ) at the boundary between cells $k$ and $k+1$. Our prescription of exchange velocities in the model (Table 1) distinguishes between a "daytime" regime $(0900$ 1600 LT) when turbulence is vigorous, and a "nighttime" regime (1600-0900 LT) when vertical motions are suppressed. Here LT refers to local (solar) time. Values for $V_{1}, V_{2}, V_{3}$ are computed on the basis of observed vertical distributions and fluxes of $\mathrm{O}_{3}$, ${ }^{222} \mathrm{Rn}$, and $\mathrm{CO}_{2}$ in the canopy and immediately above [Trumbore et al., this issue; Fan et al., this issue]. The value of $V_{1}$ is lower in the daytime than at night, reflecting the greater thermal stability of air near the ground during the day (L. C. B. Molion et al., Micrometeorological dynamics of a terre firme forest in central Amazonia during GTE/ABLE 2B mission, submitted to Journal of Geophysical Research, 1989). Values for $V_{4}, V_{5}, V_{6}, V_{7}$ are adjusted to fit the observed ${ }^{222} \mathrm{Rn}$ concentrations and $\mathrm{O}_{3}$ fluxes at canopy top [Trumbore et al., this issue; Fan et al., this issue], as well as the vertical distributions of $\mathrm{O}_{3}$ in the PBL. [Browell et al., this issue; Gregory et al., this issue; Kirchhoff et al., this issue]. The flushing time of the $0-40 \mathrm{~m}$ air column in the model (for an inert tracer emitted at the ground) is 1 hour in the daytime and 5 hours at night, in excellent agreement with the values computed by Trumbore et al. [this issue] from observations for ${ }^{222} \mathrm{Rn}$ and $\mathrm{CO}_{2}$. Turbulent exchange at the upper boundary of the model domain $\left(V_{7}\right)$ ventilates the PBL, and entrains into grid cell 7 free tropospheric air assumed to have fixed composition (Table 2). Deposition fluxes to vegetation and to the ground define the lower boundary conditions of the model, and are discussed below;

\subsection{Deposition}

The forest canopy is a sink for oxidants and for water- and lipid-soluble species, which deposit to leaves and soil. Deposition to vegetation is simulated with a resistance-in-series formulation for individual canopy grid cells [Shreffler, 1978; Meyers and Baldocchi, 1988]. The deposition rate $D_{i, k}$ (molecules $\mathrm{cm}^{-3} \mathrm{~s}^{-1}$ ) of species $i$ to vegetation in grid cell $k(k=1,3)$ is given by

$$
D_{i, k}=\frac{L_{k}}{r_{i, k} \Delta Z_{k}} C_{i, k}
$$

where $L_{k}$ is the leaf area index of grid cell $k\left(\mathrm{~cm}^{2}\right.$ leaf area per $\mathrm{cm}^{2}$ air column, counting only one side of leaf), $\Delta Z_{k}$ is the grid cell thickness (cm), and $r_{i, k}\left(\mathrm{~s} \mathrm{~cm}^{-1}\right)$ is the leaf resistance to deposition per $\mathrm{cm}^{2}$ of leaf area (counting only one side of leaf). Following Meyers and Baldocchi [1988], we express $r_{i, k}$ as a composite resistance including contributions from leaf-atmosphere boundary $\left(r_{B k}\right)$, stomatal $\left(r_{S k}\right)$, mesophyllic $\left(r_{M i, k}\right)$, and cuticular $\left(r_{C i, k}\right)$ resistances:

$$
r_{i, k}=r_{B k}+\left[\frac{1}{r_{C i, k}}+\frac{1}{\left(\Delta_{\nu} / \Delta_{i}\right) r_{S k}+r_{M i, k}}\right]^{-1}
$$

\begin{tabular}{|c|c|c|c|c|c|c|}
\hline \multirow{2}{*}{$\begin{array}{l}\text { Grid } \\
\text { Cell }\end{array}$} & \multicolumn{2}{|c|}{ Exchange Velocity, $\mathrm{cm} \mathrm{s}^{-1}$} & \multicolumn{2}{|c|}{ Top of grid cell, $\mathrm{m}$} & \multicolumn{2}{|c|}{ Equivalent $K_{2}, \mathrm{~cm}^{2} \mathrm{~s}^{-1}$} \\
\hline & $0900-1600 \mathrm{LT}$ & $1600-0900 \mathrm{LT}$ & Noon & Midnight & Noon & Midnight \\
\hline 1 & 0.13 & 0.4 & 2 & 2 & $1.3(2)$ & $4.0(2)$ \\
\hline 2 & 2 & 0.5 & 20 & 20 & $2.8(3)$ & $7.0(2)$ \\
\hline 3 & 15 & 1 & 30 & 30 & $1.5(4)$ & $1.0(3)$ \\
\hline 4 & 2 & 1 & 40 & 40 & $4.7(4)$ & $1.0(3)$ \\
\hline 5 & 2 & 1 & 500 & 50 & $1.5(5)$ & $1.0(3)$ \\
\hline 6 & 2 & 0.05 & 1500 & 60 & $1.5(5)$ & $4.9(3)$ \\
\hline 7 & 2 & 0.05 & 2000 & 2000 & $5.0(4)$ & $4.9(3)$ \\
\hline
\end{tabular}

TABLE 1. Exchange Velocities Between Model Grid Cells

The exchange velocity $V_{i}$ listed for grid cell $i$ defines the rate of turbulent mass exchange between grid cells $i$ and $i+1$, as computed from (1). For completeness, we also list the "equivalent" turbulent diffusivity at the top of grid cell $\mathrm{i}, \mathrm{K}_{\mathrm{z}, \mathrm{i}}=V_{i} \Delta Z_{i}$, where $\Delta Z_{i}$ is the distance between the centerpoints of grid cells $i$ and $i+1$. However $K_{z, i}$ is not truly equivalent to $V_{i}$ because individual grid cells are assumed well-mixed. Read $1.3(2)$ as $1.3 \times 10^{-2}$. 
TABLE 2. Upper Boundary Model Concentrations at $2000 \mathrm{~m}$ Altitude

\begin{tabular}{lcl}
\hline Species & $\begin{array}{c}\text { Concentration, } \\
\text { ppb }\end{array}$ & Reference \\
\hline Isoprene & 0.1 & Rasmussen and Khalil [1988] \\
Acetone & 0.8 & $a$ \\
$\mathrm{CO}$ & 80 & Harriss et al. [this issue $(b)]$ \\
$\mathrm{NO}$ & 0.005 & AL. Torres and KR. Hooks (submitted manuscript, 1989) \\
$\mathrm{NO}_{2}$ & 0.005 & $b$ \\
$\mathrm{PAN}$ & 0.02 & Singh et al. [this issue] \\
$\mathrm{HNO}_{3}$ & 0.2 & $b$ \\
$\mathrm{RNO}_{3}$ & 0.01 & b,c \\
$\mathrm{H}_{2} \mathrm{O}_{2}$ & 2.5 & Logan et al. [1981] \\
$\mathrm{CH}_{3} \mathrm{OOH}$ & 2 & Logan et al. [1981] \\
$\mathrm{ROOH}^{\mathrm{d}}$ & 0.01 & $b$ \\
$\mathrm{O}_{3}$ & 18 & Browell et al. [this issue] \\
\hline
\end{tabular}

astimated biogenic continental background (D. Pierotti and

S.C. Wofsy, Acetone, acetaldehyde, and other carbonyls in the atmosphere, submitted to Journal of Geophysical Research, 1989.)

${ }^{b}$ Assumed.

c A concentration of $1 \mathrm{ppb}$ is assumed in the sensitivity calculation with exogenous organic nitrates (section 6).

${ }^{d}$ Other than $\mathrm{CH}_{3} \mathrm{OOH}$.

where $\Delta_{\nu}=0.22 \mathrm{~cm}^{2} \mathrm{~s}^{-1}$ and $\Delta_{i}$ are the molecular diffusivities in air of water vapor and species $i$, respectively. We assume a total leaf area index $L=7$ for the Amazon forest canopy, based on the data of Shuttleworth et al. [1984] as discussed by Fan et al. [this issue]. This leaf area index represents a sum of contributions $L_{k}$ from each grid cell in the canopy layer:

$$
L=\sum_{1}^{3} L_{k}
$$

with $L_{1}=1, L_{2}=2$, and $L_{3}=4$ [Fan et al., this issue].

The boundary and stomatal leaf resistances used in the model (Table 3) are the average values measured at the ABLE 2B forest site by Roberts et al. [1990], as a function of time of day and altitude. Inspection of Table 3 indicates that the leaf-atmosphere boundary resistances are always small compared to the stomatal resistances, and therefore have little influence on deposition rates. The stomatal resistances are lowest in the upper canopy, and highest near the ground, presumably because of stomatal response to low light levels but also possibly because of differences in the species present at various altitudes within the canopy. In the middle and upper canopy the stomatal resistances are lowest in midmoming, and then increase progressively over the rest of the day. This diumal pattern appears to reflect the combined effects of water stress and insolation [Roberts et al., 1990].

Following Wesely [1989], we assume zero mesophyllic resistance for oxidants $\left(\mathrm{O}_{3}\right.$, peroxyacylnitrates, peroxides, $\left.\mathrm{NO}_{2}\right)$ and for water-soluble species with effective Henry's Law constants larger than $10^{3}$ moles $\mathrm{l}^{-1} \mathrm{~atm}^{-1}$ at $p \mathrm{H} 7$ (e.g., $\mathrm{HNO}_{3}, \mathrm{HNO}_{2}$, $\mathrm{CH}_{2} \mathrm{O}$, dicarbonyls). Zero mesophyllic resistance is also assumed for isoprene (which is lipid soluble) and for organic nitrates (in order to simulate the downward flux of $\mathrm{NO}_{y}$ observed by Bakwin et al. [this issue (a)]. All other species are taken to have infinite mesophyllic resistance, i.e., they are not removed at the stomata.

At night the stomata are closed, and deposition to the leaves proceeds at the outer (cuticular) surfaces only. Cuticular resistances to deposition are high except for oxidants and for highly water-soluble species [Wesely, 1989]. We adopt $r_{C}=10 \mathrm{~s} \mathrm{~cm}^{-1}$ for $\mathrm{O}_{3}$, which gives a good fit to the observed nighttime fluxes of $\mathrm{O}_{3}$ [Fan et al., this issue]. We similarly adopt $r_{C}=10 \mathrm{~s} \mathrm{~cm}^{-1}$ for other oxidants (peroxyacylnitrates, peroxides, $\mathrm{NO}_{2}$ ), and also for
$\mathrm{HNO}_{3}$ and organic nitrates. Other depositing species (i.e., other species with $r_{M}=0$ ) are assumed to be removed with $r_{C}=100 \mathrm{~s}$ $\mathrm{cm}^{-1}$, on the basis of data for water vapor [Jones, 1983].

Deposition to the ground provides an additional sink for species in grid cell 1, with flux $G_{i}$ (molecules $\mathrm{cm}^{-2} \mathrm{~s}^{-1}$ ):

$$
G_{i}=\frac{C_{i, I}}{r_{G i}}
$$

Following Wesely [1989] we assume $r_{G}=2 \mathrm{~s} \mathrm{~cm}^{-1}$ for all oxidants (and also for $\mathrm{HNO}_{3}$ and organic nitrates), and $r_{G}=5 \mathrm{~s} \mathrm{~cm}^{-1}$ for other depositing species.

TABLE 3. Leaf Resistances for Deposition to Vegetation

\begin{tabular}{lcccc}
\hline & & \multicolumn{3}{c}{ Grid Cell } \\
\cline { 4 - 5 } & Time of Day, & 1 & 2 & 3 \\
\hline LT & & $0-2$ & $2-20$ & $20-30$ \\
Bltitude range (m) & & 1.7 & 0.53 & 0.37 \\
Boundary resistance & & & & \\
Stomatal resistance & 0600 & 4.3 & 4.3 & 2.8 \\
& 0700 & 4.3 & 4.3 & 2.1 \\
& 0800 & 4.3 & 3.4 & 1.9 \\
& 0900 & 4.3 & 1.9 & 1.7 \\
& 1000 & 4.3 & 2.5 & 1.9 \\
& 1100 & 4.3 & 2.8 & 1.9 \\
& 1200 & 4.3 & 2.8 & 2.1 \\
& 1300 & 4.3 & 3.4 & 2.1 \\
& 1400 & 4.3 & 4.3 & 2.5 \\
& 1500 & 4.3 & 5.7 & 2.8 \\
& 1600 & 8.6 & 8.6 & 4.3 \\
& 1700 & 8.6 & 8.6 & 8.6 \\
& 1800 & 8.6 & 8.6 & 8.6 \\
\hline
\end{tabular}

Resistance units are $\mathrm{s} \mathrm{cm}^{-1}$ per $\mathrm{cm}^{2}$ of leaf area, counting only one side of leaf. The resistances are taken from the average values reported by Roberts et al. [1990] at the ABLE 2B forest site. The stomatal resistances as given by Roberts et al. [1990] are multiplied by $6 \Pi=0.86$, as these authors made their measurements mainly on the lower surfaces of the leaves, and reported that stomatal areas on the upper surfaces of the leaves were typically 6 times smaller than on the lower surfaces. Stomatal resistances at night are assumed infinitely large. 
Rainfall scavenges water-soluble species efficiently. Observed precipitation fluxes of sulfate and organic acids during $A B L E 2 B$ indicate a time constant of 1 day for wet removal from the PBL [Andreae et al., this issue (a)]. We use this time constant in the model to simulate wet deposition of species with effective Henry's law constants larger than $10^{3}$ moles $\mathrm{I}^{-1} \mathrm{~atm}^{-1}$ at $\mathrm{pH}$, including organic peroxides (for which solubility constants are largely unknown). Less soluble species (e.g., $\mathrm{NO}_{x}, \mathrm{PAN}$, organic nitrates) are not removed by wet deposition.

\subsection{Biogenic Emissions}

The soil in grid cell 1 is viewed as a constant source of NO and $\mathrm{CO}$ to the atmosphere. We adopt an emission flux of $8.7 \times 10^{9}$ molecules $\mathrm{cm}^{-2} \mathrm{~s}^{-1}$ for NO, which is the mean value measured for clay soils during ABLE 2B [Bakwin et al., this issue (b]. A CO emission flux of $3 \times 10^{11}$ molecules $\mathrm{cm}^{-2} \mathrm{~s}^{-1}$ is assumed, on the basis of flux estimates at canopy top by Kirchhoff and Marinho [this issue]. The CO fluxes observed by Kirchhoff and Marinho [this issue] could possibly reflect emissions from the forest vegetation, rather than from soil [Seiler, 1978]; hovever, the precise origin of this biogenic $\mathrm{CO}$ is of no consequence for our model purposes.

Isoprene provides a major sink for $\mathrm{OH}$ over the Amazon forest [Zimmerman et al., 1988]. We assume that the isoprene emission flux from the forest vegetation depends on the local air temperature and photosynthetically active radiation (PAR). The dependence on temperature is taken from Lamb et al. [1987], and the dependence on PAR is taken from Tingey et al. [1979]. The isoprene emission flux per unit area of leaf, $\phi$ (molecules $\mathrm{cm}^{-2}$ leaf $\mathrm{s}^{-1}$ ), is computed as follows:

$$
\phi=\phi_{0} e^{\zeta(T-298)} \exp \left[\frac{a}{1+e^{-b(1-c)}}\right]
$$

where $\zeta=0.1$ [Lamb et al., 1987], $a=10.2, b=0.0064, c=11$ [Tingey et al., 1979], $T$ is the local air temperature $(K), I$ is the local PAR (microeinsteins $\mathrm{m}^{-2} \mathrm{~s}^{-1}$ ), and $\phi_{\mathrm{o}}=1 \times 10^{7}$ molecules $\mathrm{cm}^{-2}$ leaf $\mathrm{s}^{-1}$ is a parameter adjusted in the model to provide a reasonable simulation of atmospheric isoprene concentrations. For a leaf at $298 \mathrm{~K}$ exposed to full sun, the isoprene emission flux calculated from (6) is $2.7 \times 10^{11}$ molecules $\mathrm{cm}^{-2}$ leaf s $\mathrm{s}^{-1}$. The rate of isoprene emission in grid cell $k, E_{k}$ (molecules $\mathrm{cm}^{-3} \mathrm{~s}^{-1}$ ), scales linearly to the vegetation density $L_{k} / \Delta Z_{k}$, and is computed as follows:

$$
E_{k}=\phi_{o} \frac{L_{k}}{\Delta Z_{k}} e^{\zeta\left(T_{k-298)}\right.} \frac{1}{z_{t}-Z_{b}} \int_{z_{b}}^{z_{t}} \exp \left[\frac{a}{1+e^{-b(l(z)-c)}}\right] d z
$$

where $z_{b}$ and $z_{t}$ are the altitudes at the bottom and at the top of grid cell $k$, respectively.

Values for $T_{k}$ range from $295 \mathrm{~K}$ in grid cell 1 in early moming to $302 \mathrm{~K}$ in grid cell 3 at midday [Fitzjarrald and Moore, this issue; Fitzjarrald et al., this issue]. This temperature range produces only a factor of 2 variation in isoprene emission rates. Light intensity plays a more important role in regulating isoprene emissions from the Amazon forest. The PAR at altitude $\mathrm{z}$ is computed by assuming that vegetation behaves as a gray absorber:

$$
I(z)=I_{T} e^{-\tau(z) / \cos \theta} \quad 0 \leq z \leq 30 \mathrm{~m}
$$

where $I_{T}$ is the PAR at the top of the canopy (30-m altitude), $\tau(z)$ is the overhead canopy optical depth at altitude $z$, and $\theta$ is the solar zenith angle. We compute $\tau(z)$ as follows:

$$
\tau(z)=k_{\mathrm{ex}} l(z) \quad 0 \leq z \leq 30 \mathrm{~m}
$$

where $k_{\mathrm{ox}}$ is the coefficient for light extinction by vegetation normalized to the leaf area index, and $l(z)$ is the leaf area index from altitude $z$ to the top of the canopy. A constant value $k_{\text {ex }}=0.5$ is assumed, corresponding to a uniform angular distribution of leaf orientations [Verstraete, 1987]. Values for $I_{T}$ are taken from the mean hourly solar irradiances for April-May measured at the Embrapa station $2 \mathrm{~km}$ from the ABLE $2 B$ forest site (O. M. R. Cabral, personal communication, 1988). Following Parsons et al. [1977], we assume that $50 \%$ of the solar radiation is photosynthetically active, and apply a conversion factor $1 \mathrm{~W}=4.60$ microeinsteins $\mathrm{s}^{-1}$ to convert the resulting PAR energy flux to a photon flux. The values of $l_{T}$ computed in this manner peak at $1270 \mathrm{mi}$ croeinsteins $\mathrm{m}^{-2} \mathrm{~s}^{-1}$ at noon, and show little asymmetry about the noontime peak.

The simulated flux of isoprene at canopy top is shown in Figure 2 as a function of time of day. This flux represents the sum of emissions from each canopy grid cell, partly balanced by deposition. The upper canopy grid cell $(20-30 \mathrm{~m})$ accounts for $98 \%$ of total isoprene emission by the forest, mainly because light attenuation inhibits emission from leaves deeper in the canopy. Vegetative emissions of acetaldehyde, organic acids, and reduced sulfur species are scaled to isoprene emission, with a scaling factor of $2 \%$ for acetaldehyde [D. Pierotti and S. C. Wofsy, Acetone, acetaldehyde, and other carbonyls in the atmosphere, submitted to Journal of Geophysical Research, 1990], and scaling factors for organic acids and sulfur species adjusted to provide simulated concentrations in harmony with observations [Talbot et al., this issue $(b)$; Andreae et al., this issue (b)]. The daily mean fluxes at canopy top of species emitted by vegetation are listed in Table 4. The flux of acetaldehyde relative to isoprene in Table 4 is higher than would be expected from the scaling of emissions; this result reflects mainly the assumed lack of acetaldehyde deposition to vegetation.

Emissions of terpenes are not included in the model. The dry season hydrocarbon measurements of Zimmerman et al. [1988] indicate that the total concentration of terpenes over the forest is less than $10 \%$ of the isoprene concentration on a molar basis, therefore terpenes should have little influence on photochemistry. However, Zimmerman et al. [1988] observed significant concentrations of

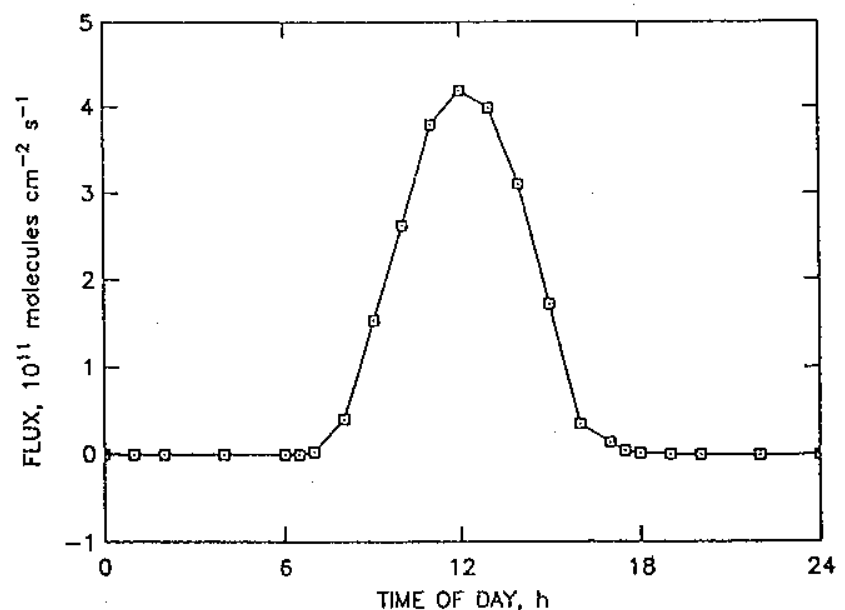

Fig. 2. Vertical flux of isoprene at $40 \mathrm{~m}$ in the model, as a function of time of day. Positive values indicate an upward flux. 
TABLE 4. Upward Fluxes at Canopy Top of Species Emitted by Vegetation

\begin{tabular}{lc}
\hline Species & $\begin{array}{c}\text { Flux, } \\
\text { molecules } \mathrm{cm}^{-2} \mathrm{~s}^{-1}\end{array}$ \\
\hline Isoprene & $9.1(10)$ \\
Acetaldehyde & $4.0(9)$ \\
Formic acid & $4.4(9)$ \\
Acetic acid & $3.7(9)$ \\
Pyruvic acid & $2.8(8)$ \\
$\mathrm{H}_{2} \mathrm{~S}$ & $1.4(9)$ \\
$\left(\mathrm{CH}_{3}\right)_{2} \mathrm{~S}$ & $3.4(8)$ \\
$\mathrm{CH}_{3} \mathrm{SH}$ & $1.7(8)$ \\
\hline
\end{tabular}

Daily mean fluxes at $30 \mathrm{~m}$ (canopy top), representing a balance between vegetative emissions and dry deposition. Read $9.1(10)$ as $9.1 \times 10^{10}$.

other nonmethane hydrocarbons (NMHCs) including alkanes, alkenes, and aromatic compounds. Biomass burning appeared to be a major source of these NMHCs, and such a source would be reduced considerably in the wet season. Unfortunately, no NMHC data are available for the wet season. In our standard model calcuIation, we neglect all NMHCs except for those listed in Table 4 and their decomposition products. A sensitivity calculation (section 9) will examine the effect of adding other NMHCs at the dry season levels reported by Zimmerman et al. [1988]. As we will see, the effect is small.

\subsection{Chemical Mechanism}

Photochemistry is simulated with the detailed mechanism of Lurmann et al. [1986], modified for low-NO $\mathrm{NO}_{x}$ conditions as described by Jacob and Wofsy [1988]. Rate constants and stoichiometries for some reactions of $\mathrm{CH}_{3} \mathrm{O}_{2}$ and $\mathrm{CH}_{3} \mathrm{CO}_{3}$ have been updated on the basis of recent kinetic data [Moortgaat et al., 1989ab]:

$$
\begin{gathered}
\mathrm{CH}_{3} \mathrm{CO}_{3}+\mathrm{CH}_{3} \mathrm{O}_{2} \stackrel{\mathrm{O}_{2}}{\rightarrow} \mathrm{CH}_{3} \mathrm{O}_{2}+\mathrm{CH}_{2} \mathrm{O}+\mathrm{HO}_{2}+\mathrm{CO}_{2} \\
k_{1}=1.8 \times 10^{-9} e^{-1800 / T} \mathrm{~cm}^{3} \text { molecule }{ }^{-1} \mathrm{~s}^{-1} \\
\mathrm{CH}_{3} \mathrm{CO}_{3}+\mathrm{CH}_{3} \mathrm{O}_{2} \rightarrow \mathrm{CH}_{3} \mathrm{COOH}+\mathrm{CH}_{2} \mathrm{O}+\mathrm{O}_{2}
\end{gathered}
$$$$
k_{2}=4.1 \times 10^{-15} e^{(2100 / r)} \mathrm{cm}^{3} \text { molecule } \mathrm{e}^{-1} \mathrm{~s}^{-1}
$$$$
\mathrm{CH}_{3} \mathrm{CO}_{3}+\mathrm{HO}_{2} \rightarrow 0.67 \mathrm{CH}_{3} \mathrm{C}(\mathrm{O}) \mathrm{OOH}
$$$$
+0.33 \mathrm{CH}_{3} \mathrm{COOH}
$$$$
+0.67 \mathrm{O}_{2}+0.33 \mathrm{O}_{3}
$$$$
k_{3}=4.3 \times 10^{-13} e^{(1040 / T)} \mathrm{cm}^{3} \text { molecule } \mathrm{s}^{-1} \mathrm{~s}^{-1}
$$$$
\mathrm{CH}_{3} \mathrm{CO}_{3}+\mathrm{CH}_{3} \mathrm{CO}_{3} \stackrel{\mathrm{O}_{2}}{\longrightarrow}>2 \mathrm{CH}_{3} \mathrm{O}_{2}+2 \mathrm{CO}_{2}
$$

$$
k_{4}=2.8 \times 10^{-12} e^{(530 / T)} \mathrm{cm}^{3} \text { molecule }{ }^{-1} \mathrm{~s}^{-1}
$$

Atmospheric oxidation of hydrocarbons in the model yields a variety of organic peroxy and peroxyacyl radicals [Lurmann et al., 1986]. We label these radicals collectively as one chemical family, $\mathrm{RO}_{2}$, and the peroxyacyl radicals collectively as $\mathrm{RCO}_{3}$, a subfamily of $\mathrm{RO}_{2}$. Kinetic data for $\mathrm{RO}_{2}$ radicals are largely limited to the smaller species $\mathrm{CH}_{3} \mathrm{O}_{2}$ and $\mathrm{CH}_{3} \mathrm{CO}_{3}$. The principal atmospheric sinks for $\mathrm{CH}_{3} \mathrm{O}_{2}$ are the reactions with $\mathrm{NO}$ and $\mathrm{HO}_{2}$, and the self-reaction. Reaction with $\mathrm{O}_{3}$ is negligibly slow [Atkinsor and Lloyd, 1984]. The $\mathrm{CH}_{3} \mathrm{CO}_{3}$ radical is consumed by simila. reactions as for $\mathrm{CH}_{3} \mathrm{O}_{2}$, and reacts in addition with $\mathrm{NO}_{2}$ to produce PAN. Following Lurmann et al. [1986], we assume that the rate constants for reactions of all $\mathrm{RO}_{2}$ radicals with $\mathrm{NO}$ and $\mathrm{HO}_{2}$ are the same as for $\mathrm{CH}_{3} \mathrm{O}_{2}$. However $\mathrm{RCO}_{3}$ radicals react with $\mathrm{HO}_{2}$ and $\mathrm{NO}_{2}$ at the same rate as $\mathrm{CH}_{3} \mathrm{CO}_{3}$. The $\mathrm{RO}_{2}-\mathrm{RO}_{2}$ reactions involving $>\mathrm{C}_{1} \mathrm{RO}_{2}$ radicals $\left(\mathrm{RO}_{2}\right.$ radicals other than $\mathrm{CH}_{3} \mathrm{O}_{2}$ or $\mathrm{CH}_{3} \mathrm{CO}_{3}$ ) are assumed negligible. Stoichiometries and rate constants for the $\mathrm{RO}_{2}$ and $\mathrm{RCO}_{3}$ reactions are as follows:

$$
\begin{aligned}
& \mathrm{RO}_{2}+\mathrm{NO} \stackrel{\mathrm{O}_{2}, \text { multisteps }}{\longrightarrow} \alpha \mathrm{R}^{\prime} \mathrm{COR} \mathrm{R}^{\prime \prime}+\beta \mathrm{NO}_{2} \\
& +(1-\beta) \mathrm{RNO}_{3} \\
& +\gamma \mathrm{HO}_{2}+\delta \mathrm{R}^{\prime \prime \prime} \mathrm{O}_{2} \\
& k_{5}=4.2 \times 10^{-12} e^{180 / T} \mathrm{~cm}^{3} \cdot \text { molecule } \mathrm{e}^{-1} \mathrm{~s}^{-1} \\
& \mathrm{RO}_{2}+\mathrm{HO}_{2} \rightarrow \mathrm{ROOH}+\mathrm{O}_{2} \\
& k_{6}=4.3 \times 10^{-13} e^{(1040 / T)} \mathrm{cm}^{3} \text { molecule } \mathrm{e}^{-1} \mathrm{~s}^{-1} \\
& \text { (for } \mathrm{RCO}_{3} \text { radicals) } \\
& k_{6}=4.5 \times 10^{-12} \mathrm{~cm}^{3} \text { molecule } \mathrm{e}^{-1} \mathrm{~s}^{-1} \\
& \text { (for non- } \mathrm{RCO}_{3} \text { radicals) } \\
& \mathrm{RCO}_{3}+\mathrm{NO}_{2} \underset{b}{\stackrel{f}{\longrightarrow}} \mathrm{RPAN} \\
& k_{7 f}=4.7 \times 10^{-12} \mathrm{~cm}^{3} \text { molecule } \mathrm{c}^{-1} \mathrm{~s}^{-1} \\
& k_{7 \mathrm{~b}}=1.95 \times 10^{16} e^{-13543 / T} \mathrm{~cm}^{3} \text { molecule } \mathrm{e}^{-1} \cdot \mathrm{s}^{-1}
\end{aligned}
$$

where $\mathrm{R}^{\prime} \mathrm{COR}^{\prime \prime}, \mathrm{RNO}_{3}, \mathrm{ROOH}$, and RPAN represent carbonyls, organic nitrates, organic peroxides, and peroxyacylnitrates, respectively. The product yields in (R5) depend on the nature of the $\mathrm{RO}_{2}$ radical; for the $\mathrm{RO}_{2}$ radicals arising from isoprene decomposition the ranges are $\alpha=0.9-1.8, \beta=0.9-1, \gamma=0.3-1$, and $\delta=0-0.6$ [Lloyd et al., 1983]. All RPAN species are assumed to decompose thermally at the same rate as PAN [Lurmann et al., 1986]. Organic peroxides produced by (R6) are removed in the model by wet and dry deposition; they may also react with $\mathrm{OH}$, or photolyze, with lifetimes of a few days against either of these chemical sinks [Jacob and Wofsy, 1988]. Organic nitrates are assumed unreactive in the atmosphere, but they are removed by dry deposition.

The UV radiation intensities are computed with a six-stream algorithm for the Rayleigh atmosphere [Logan et al., 1981], assuming an $\mathrm{O}_{3}$ column of $7.1 \times 10^{18}$ molecules $\mathrm{cm}^{-2} \mathrm{~s}^{-1}$ [Kirchhoff et al., this issue], $30 \%$ opaque cloud cover above $2000 \mathrm{~m}$ [Menzel et $a l$, this issue], and a Lambertian reflectivity of 0.1 at canopy top. Scattering of radiation by clouds within the PBL is ignored. Light extinction by aerosols is assumed to provide 0.1 total vertical optical depth at $310 \mathrm{~nm}$, varying inversely with wavelength [Logan et al., 1981]. Radiation intensities within the canopy are corrected for light extinction by vegetation following (8). Temperatures range from $302 \mathrm{~K}$ near canopy top at midday to $295 \mathrm{~K}$ in the upper PBL, and partial pressures of water vapor range from $17 \mathrm{mbar}$ in the upper PBL to 30 mbar near the ground at night, based on observations.

\subsection{Computational Procedure}

The chemical evolution of the atmosphere is computed by solving a system of coupled differential equations expressing the changes in the concentrations of species in all grid cells as a result 
f chemistry, emissions, deposition, and vertical transport. The solution is obtained by an implicit finite difference method [Richtmeyer, 1957] with time steps ranging from $30 \mathrm{~min}$ in the day to 2 hours at night. At the end of each time step the photolysis rates and the emission fluxes from vegetation are updated; the mobile grid cell boundaries are adjusted vertically, and changes in species concentrations due to entrainment are computed. We established in test simulations that these time steps are sufficiently small to ensure stable and accurate solutions.

The model simulation is conducted over 3 diurnal cycles, starting from $0000 \mathrm{LT}$. The composition of the PBL is initialized at the beginning of the simulation with free tropospheric air, i.e., the upper boundary conditions in Table 2 are taken as initial conditions. This initialization is intended to simulate the passage of a major meteorological disturbance, when air from the free troposphere is rapidly mixed with the PBL. As the simulation progresses, the concentrations of the various species increase or decrease from the initial values, approaching eventually a steady state between model sources and sinks. For a long-lived species emitted by the forest, and removed by ventilation through the top of the model domain (e.g., $\mathrm{CO}$ ), the characteristic time required to reach steady state in the model is about 7 days; a similar time is required for a species transported to the PBL from the free troposphere, and removed by deposition to the canopy (e.g., $\mathrm{O}_{3}$ ). According to data for ${ }^{222} \mathrm{Rn}$ (E. B. Pereira et al., unpublished manuscript, 1989), the residence time of air in the PBL over the Amazon Basin is roughly 3 days. Therefore we do not expect the atmosphere to reach a steady state as described by the model sources and sinks. Nevertheless, we find that changes in the simulated atmospheric composition between model days 2 and 3 are relatively small; the 24-hour average PBL concentrations of $\mathrm{O}_{3}$, $\mathrm{NO}_{x}$, isoprene, and PAN change by $-9 \%,+9 \%,+12 \%$, and $+25 \%$, respectively (the increase is greatest for PAN as it reflects the combined increases of $\mathrm{NO}_{x}$ and isoprene concentrations). We focus on the results from model day 3 as representative of the general chemical behavior of the PBL, subject to rapid exchange with the free troposphere or with air from outside the Basin every 2 or 3 days. Except if indicated otherwise, all model results presented below are from model day 3 .

\section{Chemcal Budgets IN THE CANOPY}

Figure 3 shows mean $\mathrm{O}_{3}$ concentrations observed within the canopy during ABLE 2B [Bakwin et al., this issue (a)] (right panei) as well as computed values (left panel). Reasonable agree- ment is found throughout the day, reflecting in part the adjustment of exchange velocities in the model (cf. section 2.1). The concentrations of $\mathrm{O}_{3}$ within the canopy are regulated largely by supply from aloft and deposition to vegetation, as shown in Table 5. Photochemical production provides a small additional source in the daytime ( $150 \mathrm{ppt} \mathrm{h}^{-1}$ at noon), and reaction with NO provides a small additional sink at night ( $260 \mathrm{ppt} \mathrm{h} \mathrm{h}^{-1}$ at midnight). The simulated vertical $\mathrm{O}_{3}$ fluxes at $40 \mathrm{~m}$ are in good agreement with the eddy correlation flux measurements of Fan et al. [this issue] (Figure 4). Ozone fluxes are much larger in the daytime than at night, reflecting both the opening of the stomata in the daytime and the increased turbulence at canopy top; further discussion of these factors is given by Fan et al. [this issue]. A gradual decrease in the $\mathrm{O}_{3}$ flux is found between mid-moming and afternoon, both in the model and in the observations. This asymmetry appears to follow the increase in stomatal resistances over the course of the day (Table 3).

Simulated NO concentrations within the canopy are compared in Figure 5 to the mean observations from ABLE 2B [Bakwin et al., this issue (a)]. Model results are in general harmony with these observations. The nighttime budget of $\mathrm{NO}$ in the model (Table 5) represents largely a balance between soil emission and reaction with $\mathrm{O}_{3}$. Accumulation of $\mathrm{NO}$ in the canopy air column (33 $\mathrm{ppt} \mathrm{h}^{-1}$ at midnight) is only a small term in the budget, in agreement with data from Bakwin et al. [this issue (b)], which indicate an average nighttime NO accumulation rate of $15 \pm 110 \mathrm{ppt}$ $\mathrm{h}^{-1}$ in the $0-41 \mathrm{~m}$ air column.

Nighttime oxidation of $\mathrm{NO}$ to $\mathrm{NO}_{2}$ in the model is followed by deposition of $\mathrm{NO}_{2}$ to vegetation, which limits the fraction of $\mathrm{NO}_{x}$ emitted by soil that is exported to the PBL (Table 5). The deposition of $\mathrm{NO}_{2}$ in the model follows from our assumption of a low cuticular resistance for uptake of $\mathrm{NO}_{2}$ by vegetation $\left(\mathrm{r}_{\mathrm{C}}=10 \mathrm{~s}\right.$ $\mathrm{cm}^{-1}$ ). We find that efficient nighttime uptake of $\mathrm{NO}_{2}$ by vegetation is necessary to explain the $\mathrm{NO}_{y}$ concentrations of $300-600 \mathrm{ppt}$ observed at $19-39 \mathrm{~m}$ by Bakwin et al. [this issue (a)], as these observations provide a constraint on the maximum accumulation of $\mathrm{NO}_{x}$ in the nighttime mixed layer. If $\mathrm{NO}_{x}$ were assumed not to deposit at night then the $\mathrm{NO}_{x}$ concentration simulated by the model at $30-40 \mathrm{~m}$ would exceed $1 \mathrm{ppb}$ at midnight, and $2 \mathrm{ppb}$ at dawn, inconsistent with the $\mathrm{NO}_{y}$ data. Obviously the $\mathrm{NO}_{x}$ concentrations predicted by the model are dependent on the simulation of transport; the inconsistency with the $\mathrm{NO}_{y}$ data would vanish if the ventilation rate of the nighttime mixed layer in the model were increased by a factor 3 . However such an increase would imply a flushing time of less than 2 hours for the $0.40 \mathrm{~m}$ air
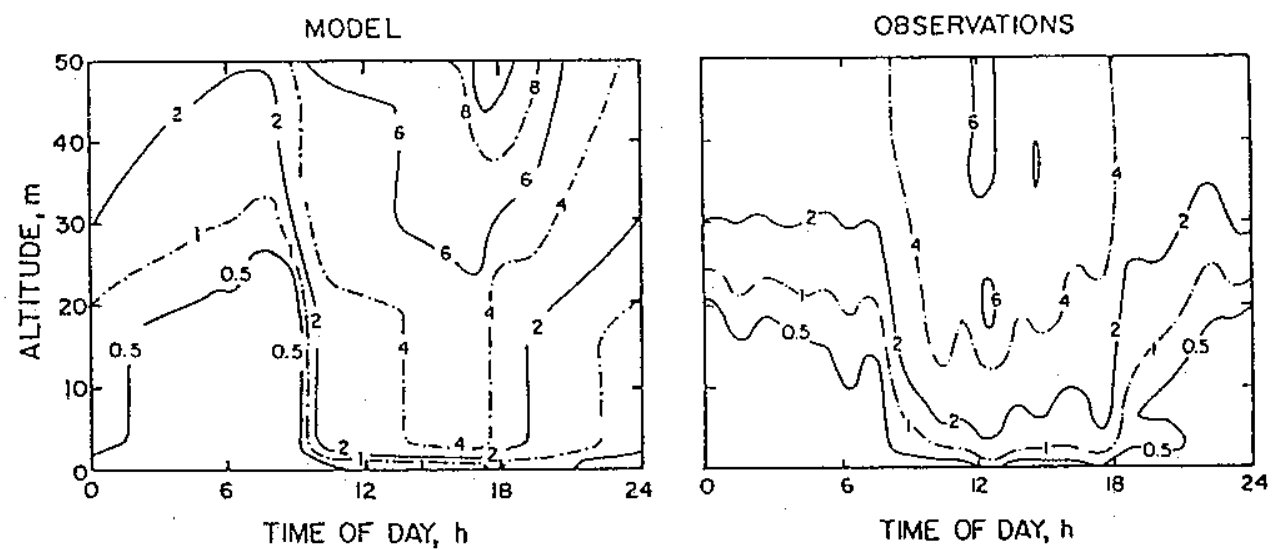

Fig. 3. Concentrations of $\mathrm{O}_{3}$ (ppb) between 0 and $50 \mathrm{~m}$, as a function of time of day. Model results (left panel) are compared to the observations of Bakwin et al. [this issue (a)] (right panel). 
TABLE 5: Budgets of $\mathrm{O}_{3}, \mathrm{NO}$, and $\mathrm{NO}_{x}$ in the $0-40 \mathrm{~m}$ air column

\begin{tabular}{|c|c|c|c|c|c|c|}
\hline & \multicolumn{2}{|c|}{$\mathrm{O}_{3}$} & \multicolumn{2}{|c|}{$\mathrm{NO}$} & \multicolumn{2}{|c|}{$\mathrm{NO}_{x}$} \\
\hline & Noon & Midnight & Noon & Midnight & Noon & Midnight \\
\hline Concentration, ppt & 4420 & 1250 & 153 & 240 & 264 & 556 \\
\hline \multicolumn{7}{|l|}{ Sources and sinks, ppt $\mathrm{h}^{-1}$} \\
\hline Soil emission & & & +330 & +330 & +330 & +330 \\
\hline Flux at $40 \mathrm{~m}$ & +9450 & +710 & -44 & -19 & -92 & -31 \\
\hline Deposition & -9190 & -740 & & & -275 & -252 \\
\hline $\mathrm{NO}+\mathrm{O}_{3}$ & -430 & -260 & -429 & -261 & & \\
\hline $\mathrm{HO}_{2}+\mathrm{NO}$ & & & -189 & -8 & & \\
\hline $\mathrm{RO}_{2}+\mathrm{NO}$ & & & -270 & -9 & & \\
\hline $\mathrm{NO}_{2}+h v$ & +580 & & +583 & & & \\
\hline PAŇ decomposition & & & & & $<1$ & $<1$ \\
\hline RPAN decomposition & & & & & +2 & $<1$ \\
\hline Accumulation, $\mathrm{ppt} \mathrm{h} \mathrm{h}^{-1}$ & +410 & -290 & -19 & +33 & -35 & +47 \\
\hline
\end{tabular}

Model results averaged over the $0.40 \mathrm{~m}$ air column.

column, while the ${ }^{222} \mathrm{Rn}$ data of Trumbore et al. [this issue] indicate a mean flushing time of 5.5 hours at night. Also, higher ventilation rates in the model would produce excessive nighttime $\mathrm{O}_{3}$ fluxes, and would require very low cuticular resistances for $\mathrm{O}_{3}$ deposition $\left(r_{c}=2.5-5 \mathrm{~s} \mathrm{~cm}^{-1}\right)$ in order to simulate the $O_{3}$ levels observed in the canopy. It appears therefore that substantial nighttime loss of $\mathrm{NO}_{x}$ must take place inside the canopy. Deposition of $\mathrm{NO}_{2}$, as simulated by the model, is a likely mechanism to explain this loss.

The observed NO concentrations show a pronounced surge shortly after sunrise (Figure 5). This surge is well simulated in the model, where it is due to photolysis of $\mathrm{NO}_{2}$ accumulated in the canopy over the course of the night. Following the surge the NO concentrations drop sharply, as the onset of daytime turbulence ventilates $\mathrm{NO}_{x}$ from the canopy. The daytime budget of $\mathrm{NO}_{x}$ in the cinopy represents a balance between soil emission of $\mathrm{NO}$, deposition of $\mathrm{NO}_{2}$ to vegetation, and ventilation to the PBL (Table 5), similarly to the nighttime budget. Ventilation and deposition rates are both enhanced in the daytime, and deposition remains the dominant term balancing soil emissions. The lower $\mathrm{NO}_{x}$ concentrations in the canopy in the daytime than at night can thus be attributed primarily to stomatal opening, rather than to enhanced turbulence.

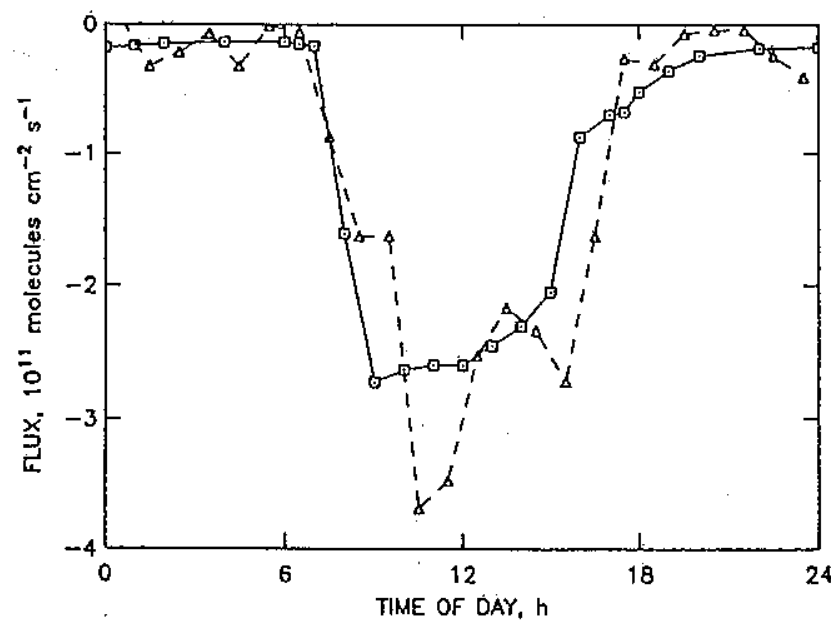

Fig. 4. Vertical flux of $\mathrm{O}_{3}$ at canopy top, as a function of time of day. Model results at $40 \mathrm{~m}$ (solid line) are compared to the eddy correlation measurements at $39 \mathrm{~m}$ of Fan et al. [this issue] (dashed line). Negative values indicate a downward flux.
Simulated upward fluxes of $\mathrm{NO}_{x}$ at $40 \mathrm{~m}$ altitude are shown in Figure 6 as a function of time of day. These can be compared to the soil emission flux of NO, $8.7 \times 10^{9}$ molecules $\mathrm{cm}^{-2} \mathrm{~s}^{-1}$. On a 24-hour average basis only $19 \%$ of $\mathrm{NO}_{x}$ emitted by soil is exported to the PBL; the balance is removed by deposition to the canopy. Export is strongest in mid-morning, when $\mathrm{NO}_{x}$ accumulated in the canopy over the previous night is ventilated to the growing mixed layer. During the remainder of the daytime hours the export of $\mathrm{NO}_{x}$ represents about $25 \%$ of the soil emission rate, declining to about $13 \%$ at night.

\section{HYDROCARBONS}

Detailed isoprene concentrations measured during ABLE 2B are not available, but a preliminary report [Dalluge et al., 1987] indicates that concentrations were similar to those observed by Rasmussen and Khalil [1988] during the dry season ABLE 2A expedition. Model results (Figure 7) are generally consistent with the aircraft observations of Rasmussen and Khalil [1988], although simulated concentrations near the surface are somewhat higher. The average model chemical lifetime of isoprene in the daytime PBL is 6.4 hours; reaction with $\mathrm{OH}$ contributes $92 \%$ of the sink and reaction with $\mathrm{O}_{3}$ contributes most of the balance. At midday, the lifetime ranges from 21 hours at canopy top to 1.5 hours in the upper $\mathrm{PBL}$, reflecting the vertical distribution of $\mathrm{OH}$ (cf. section 7). The long lifetime of isoprene near the surface allows it to be transported to relatively high altitudes, where it is then rapidly oxidized. Chemical removal of isoprene at night is slow because of the low concentration of $\mathrm{NO}_{3}$ [cf. Jacob and Wofsy, 1988].

Average concentrations of NMHCs in the PBL are listed in Table 6. The NMHCs are produced mainly by photochemical decomposition of isoprene, except for those species emitted directly by vegetation (Table 4). The low concentrations of NO in the PBL favor the formation of organic peroxides, which may be removed by wet and dry deposition ( $69 \%$ of the organic peroxide sink in the model) or recycled into the hydrocarbon pool by photolysis and reaction with $\mathrm{OH}$.

Oxidation of isoprene contributes $91 \%$ of the simulated $\mathrm{CH}_{2} \mathrm{O}$ over the forest. The simulated $\mathrm{CH}_{2} \mathrm{O}$ concentration of $0.5 \mathrm{ppb}$ is higher than observations in marine air $(\approx 0.2 \mathrm{ppb}$ [Lowe and Schmidt, 1983]), but lower than observations in rural air at northern mid-latitudes (1-2 ppb [Neitzert and Seiler; 1981; Snider and Dawson, 1985]). It appears that oxidation of isoprene can enhance 

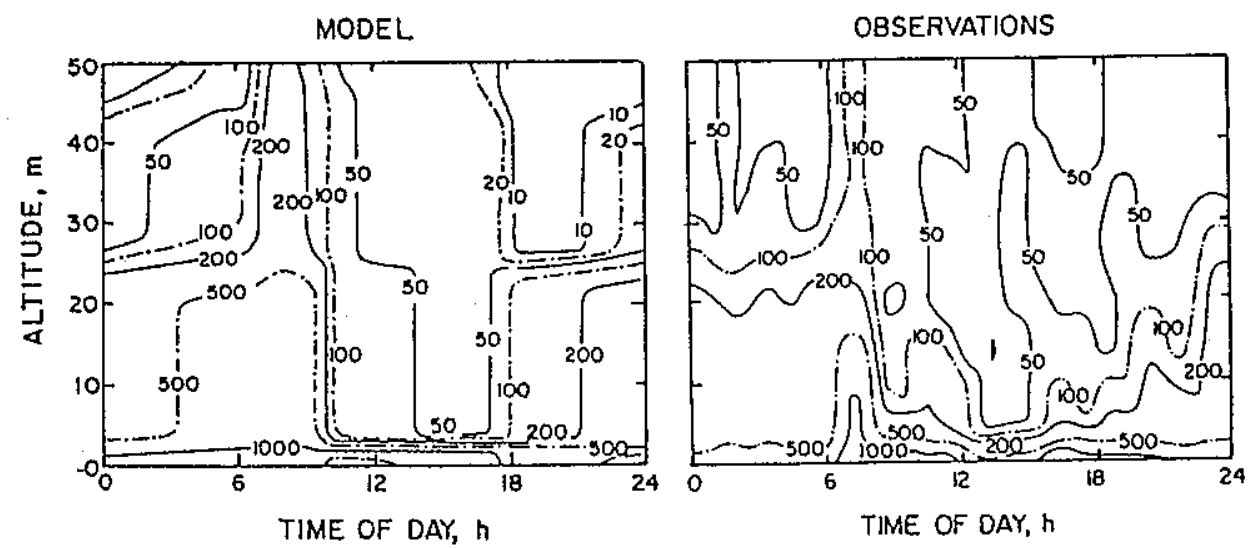

Fig. 5. Concentrations of NO (ppt) between 0 and $50 \mathrm{~m}$, as a function of time of day. Model results (left panel) are compared to the observations of Bakwin et al. [this issue (a)] (right panel).

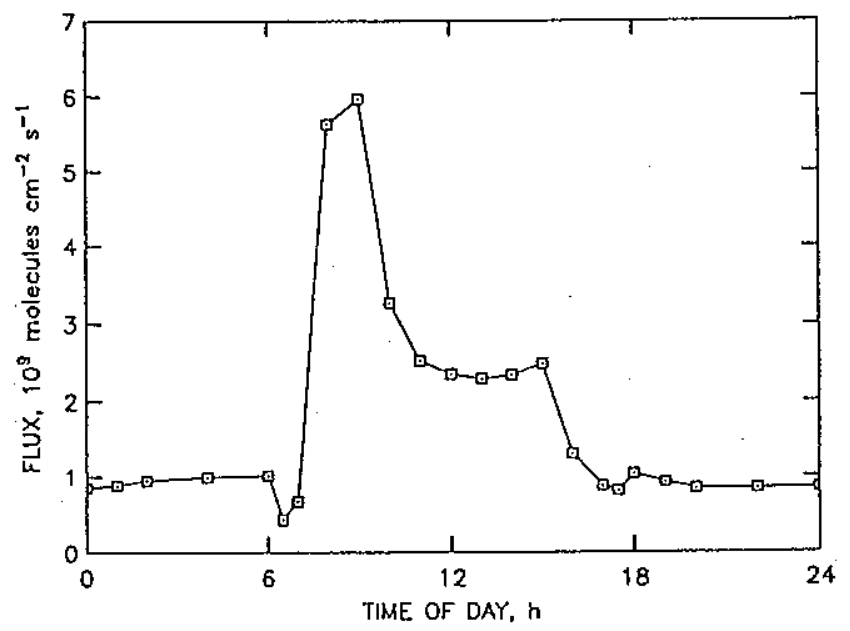

Fig. 6. Vertical flux of $\mathrm{NO}_{x}$ at $40 \mathrm{~m}$ in the model, as a function of time of day. Positive values indicate an upward flux. significantly the $\mathrm{CH}_{2} \mathrm{O}$ concentration in remote continental air as compared to marine air. At northern mid-latitudes, oxidation of anthropogenic NMHCs provides probably a major additional source of $\mathrm{CH}_{2} \mathrm{O}$ [Kasting and Singh, 1986].

Photolysis of methylglyoxal produced from decomposition of isoprene constitutes in the model the major source of the $\mathrm{CH}_{3} \mathrm{CO}_{3}$ radical (Table 7). Two other important sources are the oxidation of acetaldehyde by $\mathrm{OH}$, and the $\mathrm{RO}_{2}+\mathrm{NO}$ reaction where $\mathrm{RO}_{2}$ is a peroxy radical generated in the oxidation of methylvinylketone by $\mathrm{OH}$ [Lloyd et al., 1983]. High production rates for $\mathrm{CH}_{3} \mathrm{CO}_{3}$ displace the $\mathrm{NO}_{2} / \mathrm{PAN}$ equilibrium towards PAN, inhibiting the decomposition of PAN to $\mathrm{NO}_{x}$. As we will see below, the production of $\mathrm{CH}_{3} \mathrm{CO}_{3}$ radicals in the model is sufficiently high to lead to net formation of PAN at midday in the lower PBL.

\section{CARBON MONOXIDE}

Carbon monoxide accumulates progressively in the PBL over the course of the simulation. Starting from the free troposphere concentration of $80 \mathrm{ppb}$ assumed as initial condition, the mean $\mathrm{CO}$

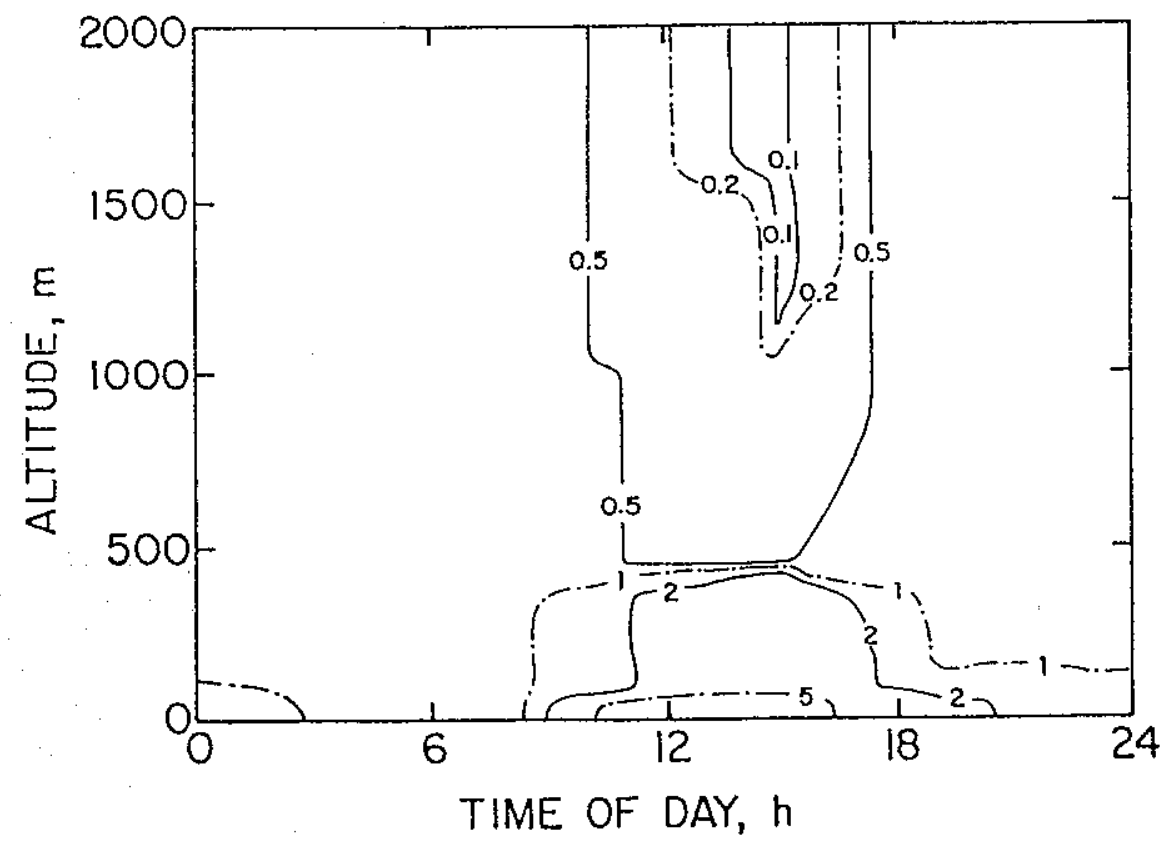

Fig. 7. Simulated concentrations of isoprene (ppb) in the PBL, as a function of altitude and time of day. 
concentration in the PBL rises to $84.1,88.0$, and $91.2 \mathrm{ppb}$ at the end of model days 1,2 , and 3 , respectively. Harriss et al [this issue $(b)]$ observed 5-10 ppb enhancements of $\mathrm{CO}$ concentration in the PBL relative to the free troposphere during ABLE 2B; model results are consistent with these observations. The net accumulation of $\mathrm{CO}$ in the PBL over the course of model day 3 is $3.2 \mathrm{ppb}$ $\mathrm{d}^{-1}$, reflecting sources from direct emission (5.9 $\left.\mathrm{ppb} \mathrm{d}^{-1}\right)$ and secondary production $\left(0.8 \mathrm{ppb} \mathrm{d}^{-1}\right)$, and sinks from ventilation to the free troposphere $\left(2.9 \mathrm{ppb} \mathrm{d}^{-1}\right)$ and reaction with $\mathrm{OH}(0.6 \mathrm{ppb}$ $\mathrm{d}^{-1}$ ). The CO concentration would reach $100 \mathrm{ppb}$ after about 7 model days, but it is unlikely that the PBL could evolve over such a long period during the wet season without a major storm disturbance or influx of oceanic air [Scala et al., this issue; E. B. Pereira et al., unpublished manuscript, 1989].

TABLE 6. Concentrations of Biogenic Hydrocarbons

\begin{tabular}{|c|c|}
\hline Species & $\begin{array}{c}\text { Concentration, } \\
\text { ppt }\end{array}$ \\
\hline lsoprene & 831 \\
\hline Methylhydroperoxide & 474 \\
\hline Organic peroxides ${ }^{*}$ & 472 \\
\hline Formaldehyde & 472 \\
\hline Methylvinylketone & 422 \\
\hline Methacrolein & 370 \\
\hline Formic acid & 156 \\
\hline Acetic acid & 153 \\
\hline$C_{3,5}$-aldehydes ${ }^{\dagger}$ & 132 \\
\hline Acetaldehyde & 129 \\
\hline Hydroxyacetaldehyde & 36 \\
\hline RNO & 32 \\
\hline Methacrylic acid & 27 \\
\hline $\mathrm{RO}_{2}$ & 20 \\
\hline RPAN & 12 \\
\hline Methylglyoxal & 9 \\
\hline$\left(\mathrm{CH}_{3}\right)_{2} \mathrm{~S}$ & 7 \\
\hline Pyruvic acid & 5 \\
\hline PAN & 5 \\
\hline $\mathrm{CH}_{3} \mathrm{SH}$ & 3 \\
\hline
\end{tabular}

Daily mean model concentrations in the PBL air column (30$2000 \mathrm{~m}$ ).

Other than methylhydroperoxide, which is listed separately.

$\dagger$ Other than methacrolein, which is listed separately.

* Biogenic organic nitrates other than peroxyacylnitrates, which are listed separately as PAN and RPAN. In the simulation with exogenous organic nitrates the daily mean $\mathrm{RNO}_{3}$ concentration in the PBL is 776 ppt (cf. Table 8).

TABLE 7. Sources of the Peroxyacetyl Radical

\begin{tabular}{lc}
\hline & $\begin{array}{c}\mathrm{CH}_{3} \mathrm{CO}_{3} \\
\text { Production Rate, } \\
\mathrm{pt} \mathrm{h}^{-1}\end{array}$ \\
\hline Methylglyoxal $+h \mathrm{v}$ & 5.4 \\
Acetaldehyde $+\mathrm{OH}$ & 2.1 \\
$\mathrm{MRO}_{2}+\mathrm{NO}$ & 2.0 \\
Acetone $+\mathrm{hv}$ & 0.7 \\
$\mathrm{ARO}_{2}+\mathrm{HO}_{2}$ & 0.4 \\
Methylvinylketone $+\mathrm{O}_{3}$ & 0.3 \\
Peroxyacetic acid $+\mathrm{OH}^{-1}$ & 0.3 \\
PAN decomposition & 0.1 \\
Miscellaneous & 0.1 \\
Total source & \\
\hline
\end{tabular}

Daily mean model rates in the PBL air column $(30-2000 \mathrm{~m})$. $\mathrm{MRO}_{2}$ and $\mathrm{ARO}_{2}$ are $\mathrm{RO}_{2}$ radicals produced from the methylvinylketone $+\mathrm{OH}$ and acetone $+\mathrm{OH}$ reactions, respectively.
Direct emission from the forest accounts for $88 \%$ of the total $\mathrm{PBL}$ source of $\mathrm{CO}$ in the model. Production of $\mathrm{CO}$ from oxidation of isoprene is small in comparison. Although isoprene emission is an important source of organic carbon to the PBL $\left(9.0 \mathrm{ppb} \mathrm{C} \mathrm{d}^{-1}\right)$, oxidation of this carbon to $\mathrm{CO}$ is inefficient because of the low photochemical reactivity of the atmosphere, and because hydrocarbon intermediates (organic peroxides, $\mathrm{CH}_{2} \mathrm{O}$ ) are removed efficiently by wet deposition. An inventory of isoprene carbon on model day 3 indicates that $39 \%$ of this carbon is deposited to the forest as organic peroxides and $\mathrm{CH}_{2} \mathrm{O}$; accumulation of hydrocarbon intermediates in the PBL and ventilation to the free troposphere account for $15 \%$ and $13 \%$ of the carbon, respectively, while $23 \%$ is oxidized directly to $\mathrm{CO}_{2}$, bypassing $\mathrm{CO}$. Only $10 \%$ of the isoprene carbon is oxidized to CO within the PBL.

Our predicted $\mathrm{CO}$ yield from oxidation of isoprene is much lower than the value of $60-80 \%$ previously derived by Zimmerman et al. [1978] from a photochemical mechanism for isoprene oxidation. Part of the reason is that we restrict our analysis to $\mathrm{CO}$ production within the PBL; however, even without such a restriction our CO yield would still be less than $30 \%$. Zimmerman et al. [1978] assumed that NO was present at sufficiently high levels to provide the only significant $\mathrm{RO}_{2}$ sink, and they did not consider deposition of hydrocarbon intermediates. If we made the same assumptions in our mechanism we would obtain a $60 \%$ CO yield from complete isoprene oxidation, consistent with the results of Zimmerman et al. [1978]; inclusion of deposition would lower the CO yield to $44 \%$, mainly because of wet deposition of $\mathrm{CH}_{2} \mathrm{O}$. The yield is lowered further by reactions of $\mathrm{RO}_{2}$ with $\mathrm{HO}_{2}$, which in the model provide about half $(48 \%)$ of the $\mathrm{RO}_{2}$ sink over the Amazon forest. The organic peroxides produced by the $\mathrm{RO}_{2}+$ $\mathrm{HO}_{2}$ reactions are primarily removed by wet deposition; they may also photolyze or react with $\mathrm{OH}$ to produce $\mathrm{C}_{3,5}$ aldehydes, which partially undergo direct oxidation to $\mathrm{CO}_{2}$ upon further reaction with OH. Obviously, our assessment of the $\mathrm{CO}$ yield from isoprene oxidation at low $\mathrm{NO}_{x}$ levels suffers from poor understanding of the atmospheric chemistry of organic peroxides.

\section{REACTTVE NTTROGEN}

Model results for concentrations of NO and PAN are shown in Figure 8 as a function of altitude and time of day. A. L. Torres and K. R. Hooks (submitted manuscript, 1989) observed NO concentrations of $12 \pm 7 \mathrm{ppt}$ in the lower PBL (up to $300 \mathrm{~m}$ ) and $6 \pm 3$ ppt in the upper PBL (300-2000 m), in harmony with model results. The mid-morning surge in NO concentrations is due to ventilation of $\mathrm{NO}_{x}$ accumulated in the canopy the previous night. Results for PAN are consistent with the observations of Singh et al. [this issue], who found daytime PBL concentrations ranging from 5 to 20 ppt. The simulated PAN concentrations are higher in the daytime than at night because downward transport from the free troposphere is faster, and because PAN decomposition in the daytime is inhibited by $\mathrm{CH}_{3} \mathrm{CO}_{3}$ radicals produced from isoprene oxidation. A weak maximum in PAN concentrations is predicted in the lower PBL at midday when the abundant supply of $\mathrm{CH}_{3} \mathrm{CO}_{3}$ radicals leads to net conversion of $\mathrm{NO}_{x}$ to PAN.

The main source of $\mathrm{NO}_{x}$ to the PBL is emission from soils, as shown in Table 8. Decomposition of PAN provides only a small source in comparison. The downward flux of PAN from the free troposphere would need to be 10 times greater than simulated in order to provide a source of reactive nitrogen to the PBL comparable to the upward flux of $\mathrm{NO}_{x}$ from the canopy; such rapid vertical transport would however be seriously inconsistent with the observed vertical distributions and fluxes of $\mathrm{O}_{3}$. Conceivably, PAN 

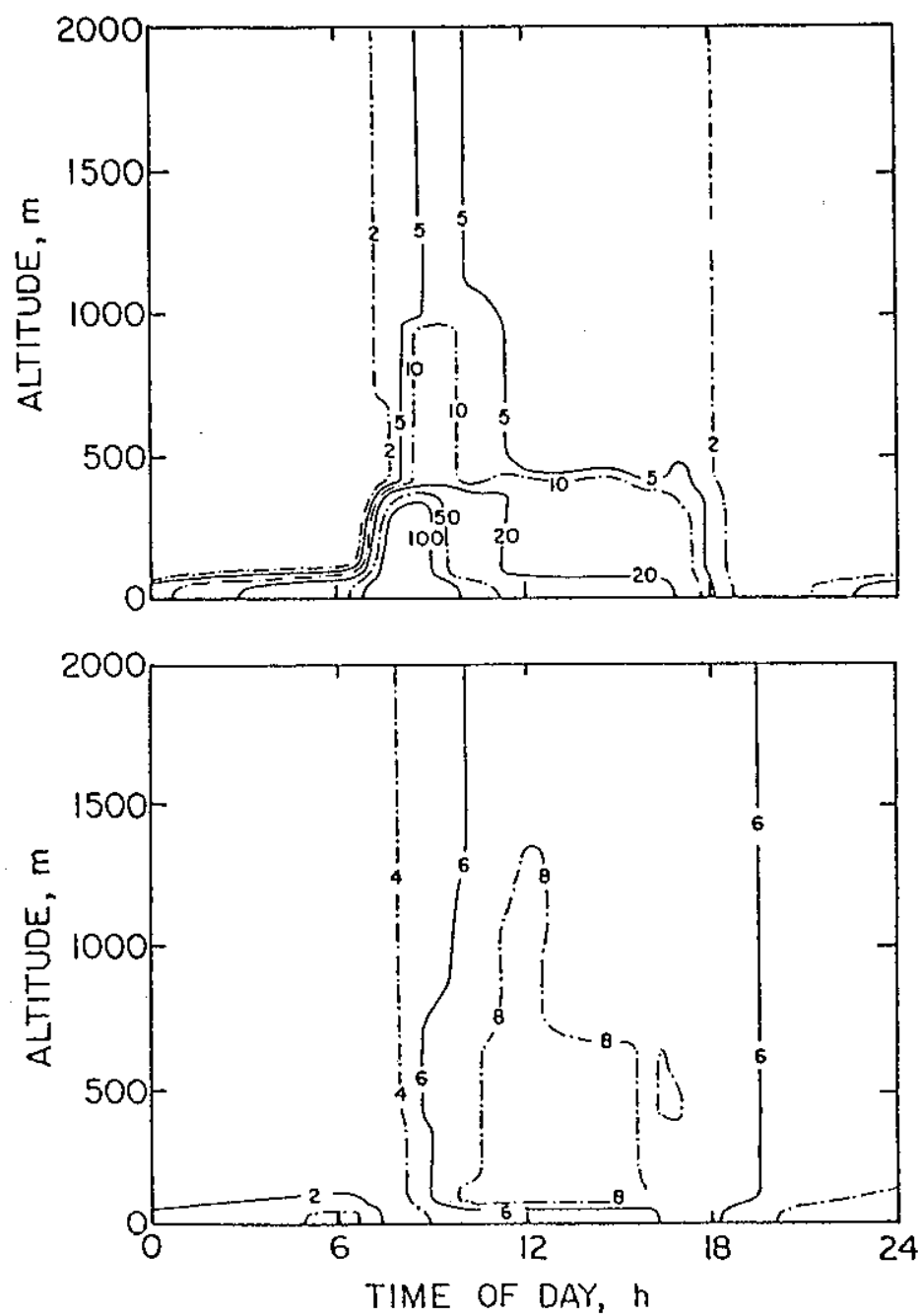

PAN

Fig. 8. Simulated concentrations of NO and PAN (ppt) in the PBL, as a function of altitude and time of day.

decomposition could make a significant contribution to the PBL $\mathrm{NO}_{x}$ budget under meteorologically disturbed conditions when mass exchange between the PBL and the free troposphere is unusually rapid, and isoprene concentrations are depleted by dilution. Under the more typical conditions simulated here, however, decomposition of PAN does not have the potential to be an important source of $\mathrm{NO}_{x}$ in the PBL.

Oxidation of $\mathrm{NO}_{x}$ in the PBL takes place on a time scale of 1 day, and produces $\mathrm{HNO}_{3}$ and organic nitrates which are subsequently removed by deposition (Table 8 ). The upward flux of $\mathrm{NO}_{x}$ at $2000 \mathrm{~m}$ in the model is very small, indicating negligible export of biogenic $\mathrm{NO}_{x}$ to the free troposphere. This inefficacy of $\mathrm{NO}_{x}$ export from the PBL follows in part from the rapid oxidation of $\mathrm{NO}_{x}$, and in part from the model assumption of 10 ppt $\mathrm{NO}_{x}$ as an upper boundary condition at $2000 \mathrm{~m}$ (based on the $\mathrm{NO}$ measurements of A. L. Torres and K. R. Hooks, submitted manuscript, 1989). Model results thus imply that soil emissions make little contribution to the $\mathrm{NO}_{x}$ budget above $2000 \mathrm{~m}$. Possible sources of $\mathrm{NO}_{x}$ above $2000 \mathrm{~m}$ include lightning [Crutzen et al., 1985] and thermal decomposition of PAN [Singh et al., this issue].

The concentrations of $\mathrm{NO}_{y}$ measured at $39 \mathrm{~m}$ altitude during ABLE $2 B$ averaged 450 ppt, with little diumal variation [Bakwin et al., this issue (a)]. Only a small fraction of this $\mathrm{NO}_{\mathrm{y}}$ can be explained by the sum of the observed concentrations of NO, PAN, and $\mathrm{HNO}_{3}$ [Bakwin et al., this issue (a); Singh et al., this issue;
[Talbot et al., this issue (a)]. Concentrations of $\mathrm{NO}_{2}, \mathrm{HNO}_{2}$, and biogenic organic nitrates predicted by the model from oxidation of biogenic $\mathrm{NO}$ are insufficient to account for the missing $\mathrm{NO}_{y}$, particularly in the daytime (Table 9; Figure 9). We conclude that a

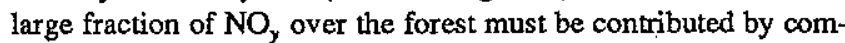
pounds of non-biogenic origin, presumably organic nitrates transported from Manaus or from sources outside the Amazon Basin.

This hypothesis of a non-biogenic source for $\mathrm{NO}_{y}$ was examined further by imposing a high concentration $(1 \mathrm{ppb})$ of exogenous organic nitrates at the upper boundary of the model domain $(2000 \mathrm{~m})$. These organic nitrates were assumed to be chemically inert in the PBL, and to be removed by dry deposition to the forest. As shown in Figure 9, such an $\mathrm{NO}_{\text {y }}$ source improves the simulation of the observed $\mathrm{NO}_{y}$ concentrations. The exogenous organic nitrates in the model contribute $70 \%$ of the $\mathrm{NO}_{\text {, }}$ observed at $39 \mathrm{~m}$ at noon, and $30 \%$ at midnight (Table 9). The lower fraction at night is due to $\mathrm{NO}_{x}$ accumulation in the nighttime mixed layer, and depletion of organic nitrates by deposition to the canopy. The dry deposition of organic nitrates at night offsets the increasing levels of $\mathrm{NO}_{x}$, thus explaining the lack of diumal variation in $\mathrm{NO}_{\mathrm{y}}$ levels reported by Bakwin et al. [this issue (a)].

The $\mathrm{NO}_{y}$ measurements of Bakwin et al. [this issue (a)] indicate higher $\mathrm{NO}_{\mathrm{y}}$ concentrations at $39 \mathrm{~m}$ than at $19 \mathrm{~m}$, implying a net downward flux of $\mathrm{NO}_{y}$ from the atmosphere to the canopy. This 
TABLE 8. Budgets of Reactive Nitrogen Species in the PBL Air Column $(30-2000 \mathrm{~m})$

\begin{tabular}{|c|c|c|c|c|c|c|}
\hline Species & $N O_{x}$ & PAN & RPAN & $\mathrm{HNO}_{3}$ & $\mathrm{RNO}_{3}^{*}$ & $\mathrm{NO}_{\mathrm{y}}^{*}$ \\
\hline Concentration, ppt & 26 & 5.2 & 12 & 46 & 776 & 865 \\
\hline Sources and sinks, ppt $\mathrm{d}^{-1}$ & & & & & & \\
\hline $\begin{array}{l}\text { Flux at canopy top }(30 \mathrm{~m})^{\dagger} \\
\text { Wet deposition }\end{array}$ & +33.4 & -1.5 & -1.5 & $\begin{array}{r}-5.7 \\
-45.7\end{array}$ & -106.1 & $\begin{array}{l}-81.4 \\
-45.7\end{array}$ \\
\hline Flux at $2000 \mathrm{~m}$ & -1.0 & +3.6 & -2.7 & +35.8 & +35.6 & +71.3 \\
\hline $\mathrm{PAN} \rightarrow \mathrm{NO}_{x}$ & +1.4 & -1.4 & & & & \\
\hline $\mathrm{NO}_{x} \rightarrow \mathrm{RPAN}$ & -6.0 & & +6.0 & & & \\
\hline $\mathrm{NO}_{x} \rightarrow \mathrm{HNO}_{3}$ & -7.8 & & & +7.8 & & \\
\hline $\mathrm{NO}_{x} \rightarrow \mathrm{RNO}_{3}$ & -16.2 & & & & +16.2 & \\
\hline Accumulation, ppt $\mathrm{d}^{-1}$ & +2.7 & +0.7 & +1.8 & -7.8 & -54.3 & -55.8 \\
\hline
\end{tabular}

Daily mean model values in the PBL air column $(30-2000 \mathrm{~m})$.

- Including exogenous organic nitrates (see text).

${ }^{\dagger}$ Not including wet deposition.

TABLE 9. Simulated Concentrations of $\mathrm{NO}_{v}$ Species in Grid Cell $4(30-40 \mathrm{~m})$

\begin{tabular}{lrr}
\hline & \multicolumn{2}{c}{ Concentration, ppt } \\
\cline { 2 - 3 } & Noon & Midnight \\
\hline $\mathrm{NO}$ & 41 & 29 \\
$\mathrm{NO}_{2}$ & 66 & 291 \\
$\mathrm{PAN}$ & 5 & 2 \\
$\mathrm{RPAN}$ & 3 & 2 \\
$\mathrm{HNO}_{3}$ & 16 & 13 \\
$\mathrm{RNO}_{3}^{*}$ & 18 & 13 \\
$\mathrm{RNO}_{3}$ & 328 & 148 \\
Total NO $_{\mathrm{y}}$ (model) & 477 & 498 \\
Total NO & & \\
\hline
\end{tabular}

* Biogenic organic nitrates other than PAN or RPAN.

$t$ Exogenous organic nitrates.

* Including exogenous organic nitrates.

5 At $39 \mathrm{~m}$ altitude [Bakwin et al., this issue (a)].

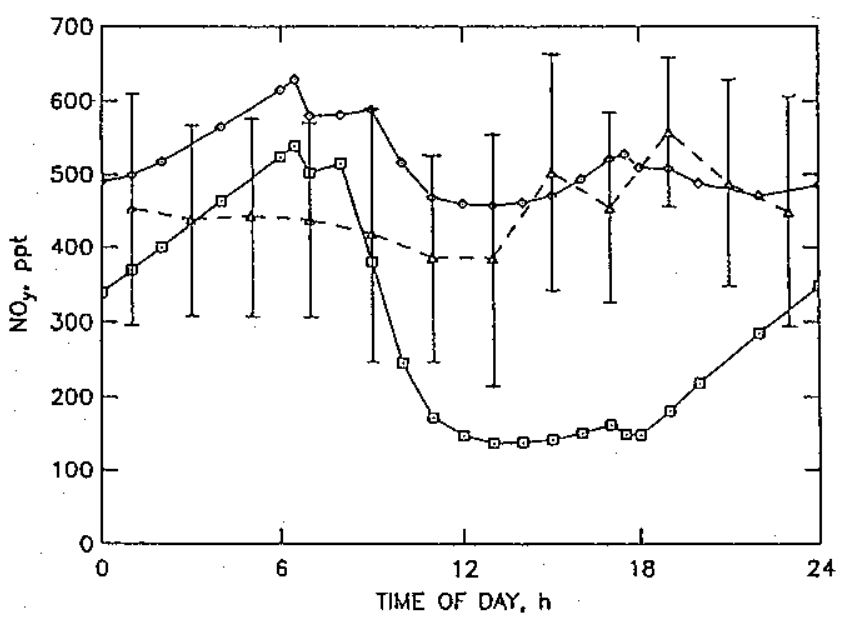

Fig. 9. Concentrations of $\mathrm{NO}_{\mathrm{y}}$ just above the canopy, as a function of time of day. Model results for grid cell $4(30-40 \mathrm{~m})$ are shown as solid lines, for the simulation with and without exogenous organic nitrates (diamonds and squares, respectively). The observations of Bakwin et al. [this issue (a)] at $39 \mathrm{~m}$ are shown as the dashed line with error bars (mean \pm standard deviation). flux represents the sum of contributions from $\mathrm{NO}_{y}$ species removed by deposition (e.g., PAN, $\mathrm{HNO}_{3}$, organic nitrates), partly balanced by soil emissions of NO. Bakwin et al. [this issue (a)] defined $\mathrm{NO}_{r}=\mathrm{NO}_{y}-\mathrm{NO}$ as the ensemble of $\mathrm{NO}_{y}$ species removed by deposition, and computed the dry deposition fluxes of $\mathrm{NO}_{r}$ on the basis of the observed $\mathrm{NO}_{\mathrm{r}}$ gradients by assuming similarity with $\mathrm{O}_{3}$ deposition. The ensemble of $\mathrm{NO}_{r}$ species defined in this manner includes $\mathrm{NO}_{2}$, which in the model has a net flux upward at $40 \mathrm{~m}$ (Table 5), therefore, the assumption of similarity between $\mathrm{NO}_{r}$ and $\mathrm{O}_{3}$ may not be fully warranted. The model simulation allows us to examine this question.

We compare in Figure 10 the NO, fluxes computed by Bakwin et al. [this issue (a)] to the model values for the simulation with exogenous organic nitrates. Good agreement is found throughout the day, except that the high value computed by Bakwin et al. [this issue $(a)]$ at $1300 \mathrm{LT}$ is not reproduced by the model. Most of the $\mathrm{NO}$, flux in the model is contributed by the exogenous organic nitrates. The daily mean flux of $\mathrm{NO}_{r}$ in the model is $-5.2 \times 10^{9}$ molecules $\mathrm{cm}^{-2} \mathrm{~s}^{-1}$, compared to $-6.5 \times 10^{9}$ molecules $\mathrm{cm}^{-2} \mathrm{~s}^{-1}$ reported by Bakwin et al. [this issue (a)] (negative values indicate a downward flux). Correction for the $\mathrm{NO}_{2}$ upward flux is small; the

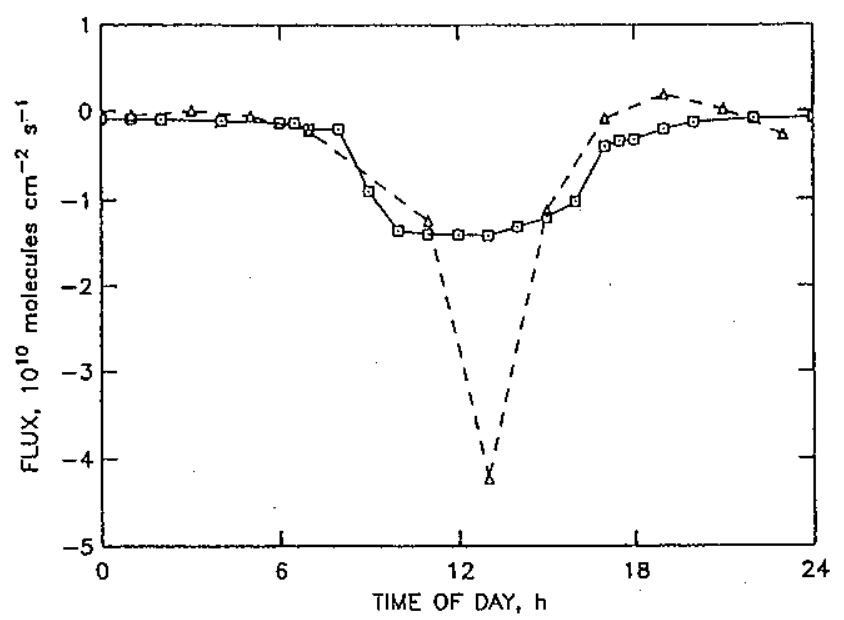

Fig. 10. Vertical flux of $\mathrm{NO}_{r}=\mathrm{NO}_{y}-\mathrm{NO}$ at $40 \mathrm{~m}$, as a function of time of day. Model results (solid line) are compared to values computed from observed $\mathrm{NO}_{r}$ gradients [Bakwin et al., this issue (a)] (dashed line). Negative values indicate a downward flux. 
Haily mean flux of $\mathrm{NO}_{r}-\mathrm{NO}_{2}=\mathrm{NO}_{y}-\mathrm{NO}_{x}$ in the model is $-5.8 \mathrm{x}$ $10^{9}$ molecules $\mathrm{cm}^{-2} \mathrm{~s}^{-1}$, only $12 \%$ larger than the $\mathrm{NO}_{r}$ flux. The daily mean flux of $\mathrm{NO}_{y}$ in the model is $-4.1 \times 10^{9}$ molecules $\mathrm{cm}^{-2}$ $\mathrm{s}^{-1}$. These dry deposition fluxes can be compared to the mean $\mathrm{NO}_{3}^{-}$wet deposition flux of $8.8 \times 10^{9}$ molecules $\mathrm{cm}^{-2} \mathrm{~s}^{-1}$ measured by Andreae et al. [this issue (a)] at the Embrapa sites during $\mathrm{ABLE} 2 \mathrm{~B}$. It appears that more $\mathrm{NO}_{\mathrm{y}}$ is supplied to the forest by wet deposition than by dry deposition.

\section{ODD HYDROGEN}

Model concentrations of $\mathrm{OH}$ in the PBL are shown in Figure 11, and 24-hour average production and removal rates are listed in Table 10. Photolysis of $\mathrm{O}_{3}$ accounts for $73 \%$ of the $\mathrm{OH}$ source, while reactions with isoprene and $\mathrm{CO}$ account for $58 \%$ of the sink. The $\mathrm{OH}$ concentration increases as the concentration of $\mathrm{O}_{3}$ increases, and as the concentration of isoprene decreases; it is relatively insensitive to the concentration of $\mathrm{NO}_{x}$ as long as the latter is sufficiently low that photolysis of $\mathrm{O}_{3}$ dominates over the reaction $\mathrm{HO}_{2}+\mathrm{NO}$ as a source of $\mathrm{OH}$. Maximum $\mathrm{OH}$ concentrations of $2.4 \times 10^{6}$ molecules $\mathrm{cm}^{-3}$ are predicted at $1400 \mathrm{LT}$ in the upper PBL, reflecting the relatively high levels of $\mathrm{O}_{3}$ at that altitude and the low concentrations of isoprene. The $\mathrm{OH}$ concentrations near the canopy are much lower than aloft and show less diurnal variation, because the effect of increased $\mathrm{O}_{3}$ photolysis at midday is offset by an increase in the isoprene concentration.

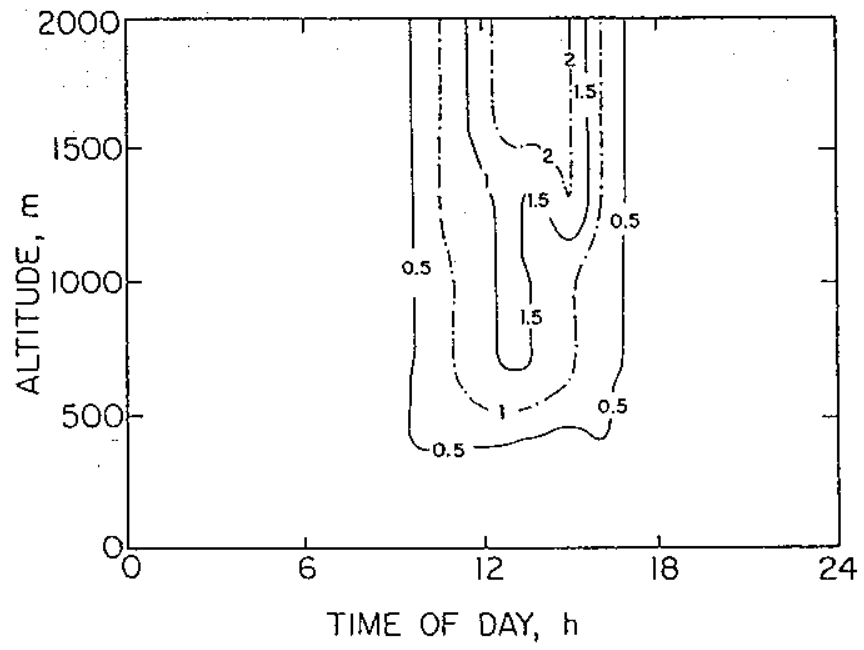

Fig. 11. Simulated concentrations of $\mathrm{OH}\left(10^{6}\right.$ molecules $\left.\mathrm{cm}^{-3}\right)$ in the $\mathrm{PBL}$, as a function of altitude and time of day.

It is convenient to group $\mathrm{OH}, \mathrm{HO}_{2}$, and $\mathrm{RO}_{2}$ into one chemical family, odd hydrogen, and to refer to the ensemble of conversions between these species as the odd hydrogen cycle [Logan et al., 1981]. The principal odd hydrogen source in the model is the photolysis of $\mathrm{O}_{3}$, while the main sink is the formation of organic peroxides by peroxy-peroxy reactions (Table 11), Odd hydrogen cycling produces $\mathrm{O}_{3}$ by the reactions

$$
\begin{aligned}
& \mathrm{RO}_{2}+\mathrm{NO} \rightarrow \mathrm{RO}+\mathrm{NO}_{2} \\
& \mathrm{HO}_{2}+\mathrm{NO} \rightarrow \mathrm{OH}+\mathrm{NO}_{2} \\
& \mathrm{NO}_{2}+h v \stackrel{\mathrm{O}_{2}}{\longrightarrow}>\mathrm{NO}+\mathrm{O}_{3}
\end{aligned}
$$

and consumes $\mathrm{O}_{3}$ by the reaction
TABLE 10. Sources and Sinks of OH

Values

Concentration,

molecules $\mathrm{cm}^{-3}$

Sources,

molecules $\mathrm{cm}^{-3} \mathrm{~s}^{-1}$

$\begin{array}{ll}\mathrm{O}\left({ }^{1} D\right)+\mathrm{H}_{2} \mathrm{O} & 6.7(5) \\ \mathrm{HO}_{2}+\mathrm{NO} & 1.0(5) \\ \mathrm{H}_{2} \mathrm{O}_{2}+h v & 5.8(4) \\ \mathrm{HO}_{2}+\mathrm{O}_{3} & 4.8(4) \\ \mathrm{ROOH}+h v & 4.1(4)\end{array}$

Total

Sinks,

molecules $\mathrm{cm}^{-3} \mathrm{~s}^{-1}$

Isoprene $+\mathrm{OH}$

$\mathrm{CO}+\mathrm{OH}$

$\mathrm{CH}_{4}+\mathrm{OH}$

Methacrolein $+\mathrm{OH}$

Methylvinylketone $+\mathrm{OH}$

$\mathrm{ROOH}+\mathrm{OH} \quad 4.4(4)$

$\mathrm{CH}_{2} \mathrm{O}+\mathrm{OH}$

$\mathrm{H}_{2}+\mathrm{OH} \quad 2.4(4)$

$\mathrm{C}_{3-5}$ aldehydes $+\mathrm{OH}$

Acetaldehyde $+\mathrm{OH}$

Miscellaneous* 3.9(4)

Total

Daily mean model vahues in the PBL air column $(30-2000 \mathrm{~m})$. Read 3.5(5) as $3.5 \times 10^{5}$.

* Sum of minor sinks with individual rates $<1 \times 10^{4}$ molecules $\mathrm{cm}^{-3} \mathrm{~s}^{-1}$.

$$
\mathrm{HO}_{2}+\mathrm{O}_{3} \rightarrow \mathrm{OH}+2 \mathrm{O}_{2}
$$

The RO radical produced in (R8) decomposes rapidly to yield $\mathrm{HO}_{2}$ or a smaller $\mathrm{R}^{\prime} \mathrm{O}_{2}$ molecule, conserving odd hydrogen. Under moderately polluted conditions (0.1-10 $\mathrm{ppb} \mathrm{NO}$ ) the rate of odd hydrogen cycling is much faster than the rate of odd hydrogen loss, and (R9) dominates over (R11), so that efficient photochemical production of $\mathrm{O}_{3}$ takes place from a relatively small odd hydrogen source [cf. Lin et al., 1988]. Over the Amazon forest, however, the concentration of $\mathrm{NO}_{x}$ is so low that odd hydrogen loss dominates over odd hydrogen cycling. Figure 12 illustrates the principal pathways of the odd hydrogen cycle in the simulation, for the lower PBL and for the upper PBL at noon. In both cases, odd hydrogen removal by formation of peroxides is faster than the conversion $\mathrm{HO}_{2}->\mathrm{OH}$ that recycles odd hydrogen. As a result, photochemical production of $\mathrm{O}_{3}$ is inefficient. Net photochemical loss of $\mathrm{O}_{3}$ takes place in the upper PBL, as discussed further below.

\section{OZONE}

Model $\mathrm{O}_{3}$ concentrations in the PBL range from 6 to $16 \mathrm{ppb}$, in harmony with the ABLE 2B aircraft observations (Figure 13). The simulated budget for $\mathrm{O}_{3}$ in the PBL is regulated by downward transport from the free troposphere (supplying $1.2 \mathrm{ppb} \mathrm{d}^{-1}$ to the PBL) and losses from deposition to the canopy $\left(-2.0 \mathrm{ppb} \mathrm{d}^{-1}\right)$ and photochemistry $\left(-0.05 \mathrm{ppb} \mathrm{d}^{-1}\right)$. This budget implies a small net loss of $\mathrm{O}_{3}$ in the PBL $\left(-0.9 \mathrm{ppb} \mathrm{d}^{-1}\right.$ on model day 3). A steady state concentration for $\mathrm{O}_{3}$ would be approached after about 7 days, 
but as we have previously pointed out (section 6) it is unlikely that the PBL could evolve such a long period without a major storm or intrision of air from outside the Basin. We presume that these disturbances provide the missing source to close the $\mathrm{O}_{3}$ budget in the PBL.

TABLE 11. Sources and Sinks of Odd Hydrogen

Concentration, molecules $\mathrm{cm}^{-3}$

Values

Sources, molecules $\mathrm{cm}^{-3} \mathrm{~s}^{-1}$

$$
\begin{aligned}
& \mathrm{O}\left({ }^{1} D\right)+\mathrm{H}_{2} \mathrm{O} \\
& \mathrm{CH}_{2} \mathrm{O}+h v \\
& \mathrm{ROOH}+h v \\
& \text { Methylglyoxal + hv } \\
& \mathrm{H}_{2} \mathrm{O}_{2}+h v
\end{aligned}
$$

Total

Sinks, molecules $\mathrm{cm}^{-3} \mathrm{~s}^{-1}$

$$
\begin{aligned}
& \mathrm{RO}_{2}+\mathrm{HO}_{2} \\
& \mathrm{HO}_{2}+\mathrm{HO}_{2} \\
& \mathrm{CH}_{3} \mathrm{CO}_{3}+\mathrm{CH}_{3} \mathrm{O}_{2} \\
& \mathrm{OH}+\mathrm{HO}_{2} \\
& \mathrm{CH}_{3} \mathrm{O}_{2}+\mathrm{CH}_{3} \mathrm{O}_{2}
\end{aligned}
$$

Total

Daily mean model values in the PBL air column $(30-2000 \mathrm{~m})$. The odd hydrogen family includes $\mathrm{OH}, \mathrm{HO}_{2}$, and all $\mathrm{RO}_{2}$ species. Read $5.6(8)$ as $5.6 \times 10^{8}$.

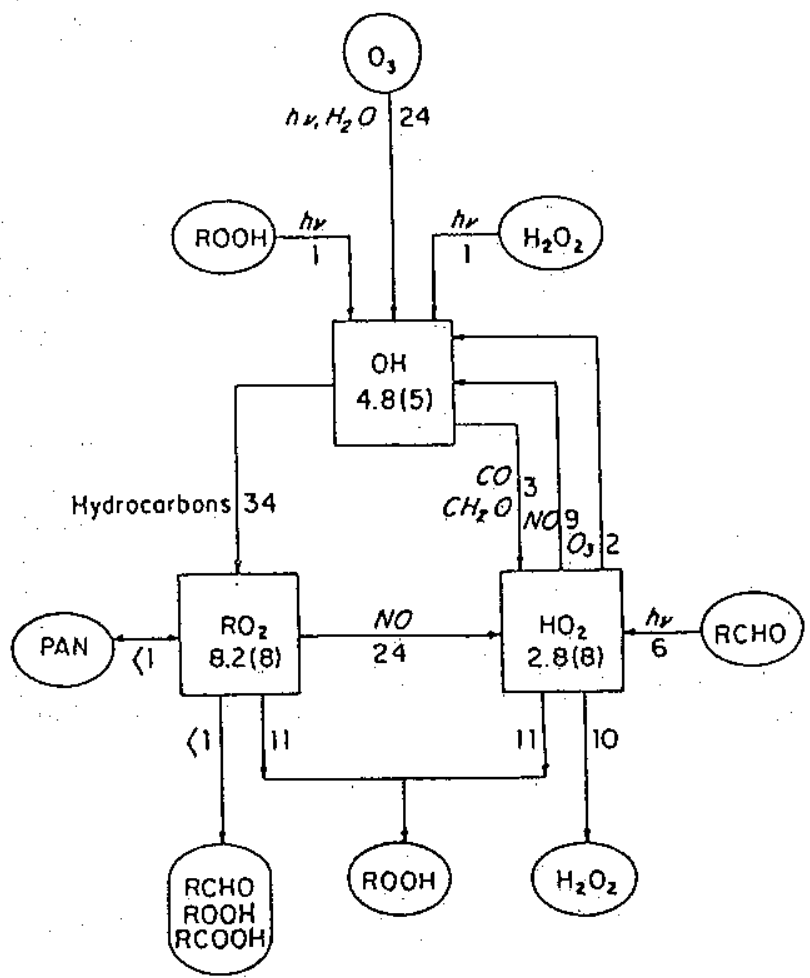

Photochemical production and loss of $\mathrm{O}_{3}$ in the PBL is strongly dependent on altitude, as shown in Figure 14. Photochemical loss of $\mathrm{O}_{3}$ takes place above 500 in during the aftemoon hours, while photochemical production takes place in the region immediately above the canopy where NO concentrations are relatively high. Comparison of Figures 8 and 14 indicates that the crossover NO concentration for $\mathrm{O}_{3}$ production in the model is about $5 \mathrm{ppt}$. Photochemistry provides a net loss of $\mathrm{O}_{3}$ for concentrations of $\mathrm{NO}$ below that level.

A simple analytical expression for the crossover NO concentration can be obtained by assuming that $\mathrm{O}_{3}$ photolysis is the only odd hydrogen source, that $\mathrm{RO}_{2}+\mathrm{NO}$ is the only reaction producing $\mathrm{O}_{3}$, and that formation of organic peroxides is the only odd hydrogen sink (see Figure 12). The $\mathrm{O}_{3}$ yield $Y$ per $\mathrm{O}_{3}$ photolysis reaction (producing 2 odd hydrogen molecules) is then given by.

$$
Y=\frac{k_{5}[\mathrm{NO}]}{k_{6}\left[\mathrm{HO}_{2}\right]}
$$

where $k_{5}$ and $k_{6}$ are the rate constants for the reactions $\mathrm{RO}_{2}+\mathrm{NO}$ (R5) and $\mathrm{RO}_{2}+\mathrm{HO}_{2}(\mathrm{R} 6)$, respectively. The crossover NO concentration for $\mathrm{O}_{3}$ production is given by $Y=1$, or

$$
[\mathrm{NO}]=\frac{k_{6}}{k_{5}}\left[\mathrm{HO}_{2}\right]
$$

The concentration of $\mathrm{HO}_{2}$ in the upper PBL at noon is $10 \mathrm{ppt}$, and the daytime average PBL concentration is $7 \mathrm{ppt}$, corresponding to NO crossover concentrations of 6 and $4 \mathrm{ppt}$, respectively. The factors regulating production and loss of $\mathrm{O}_{3}$ over the Amazon forest

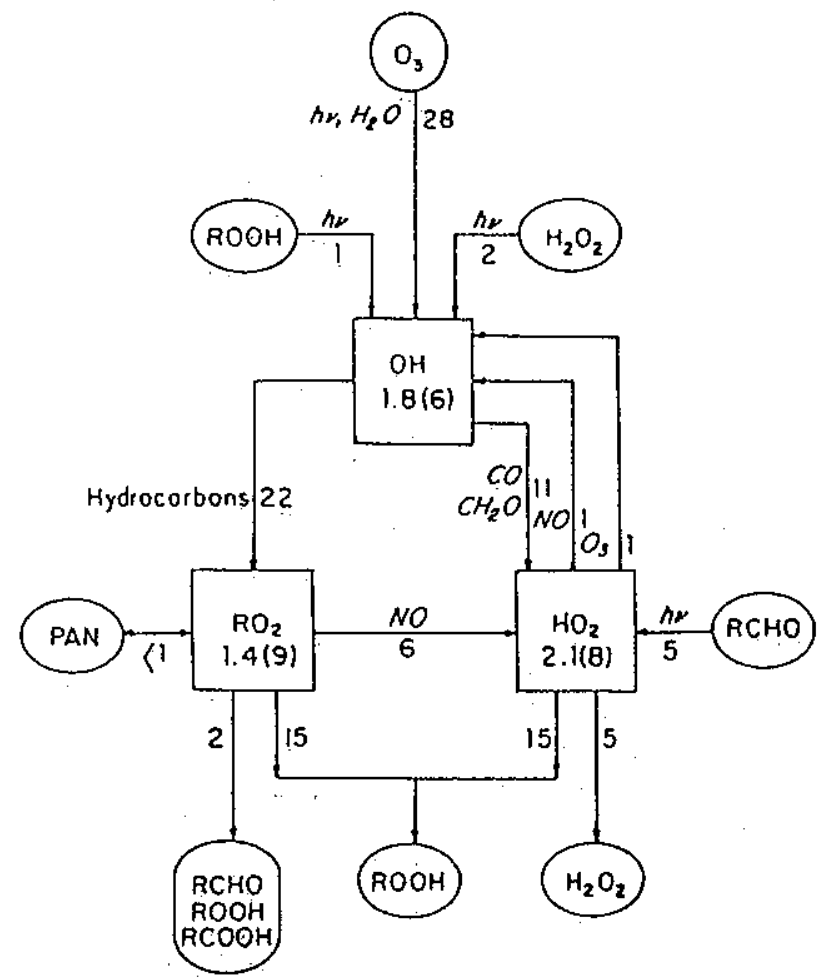

Fig. 12. Odd hydrogen cycle in the model at noon. The major reaction psthways are indicated. Concentrations are in units of molecules $\mathrm{cm}^{-3}$, and transformation rates are in units of $10^{5}$ molecules odd hydroger $\mathrm{cm}^{-3} \mathrm{~s}^{-1}$. Read 4.8(5) as $4.8 \times 10^{5}$ molecules $\mathrm{cm}^{-3}$. Results for the lower PBL $(40-500 \mathrm{~m})$ are shown in the left panel. Results for the upper PBL (1500-2000 m) are shown in the right panel. 


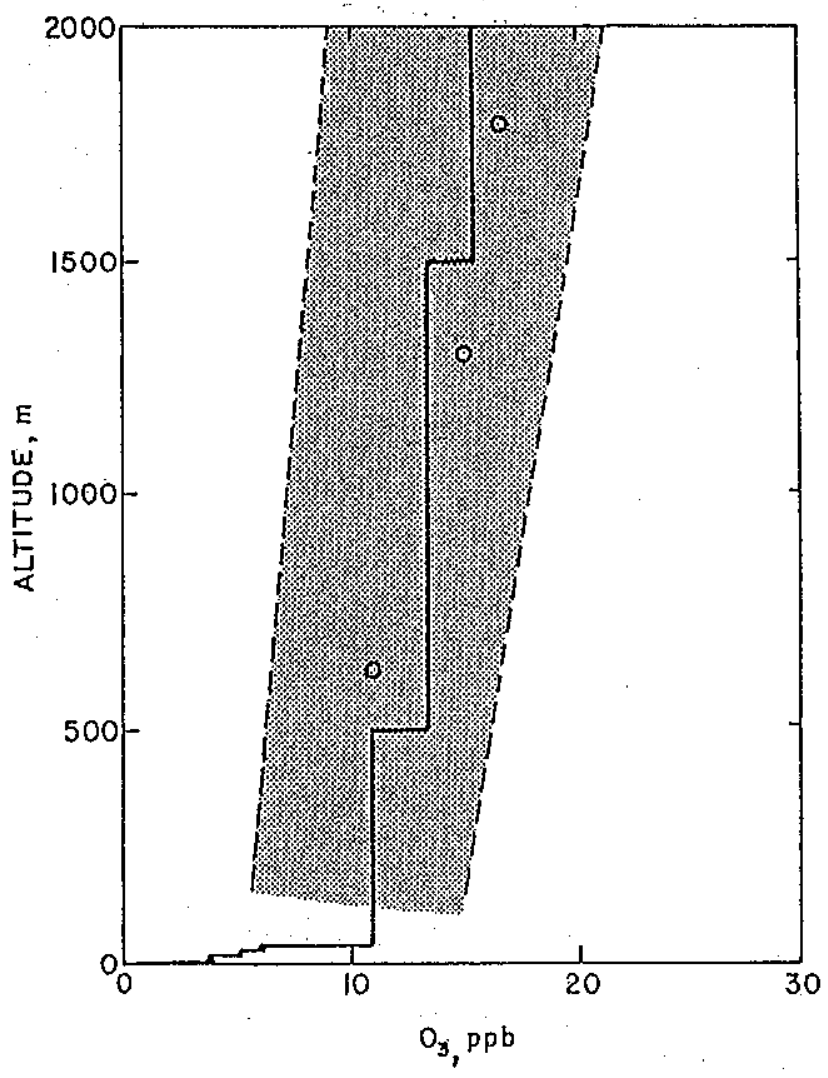

Fig. 13. Concentrations of $\mathrm{O}_{3}$ in the PBL as a function of altitude. Model results at noon (solid line) are compared to the range of concentrations observed from aircraft during ABLE 2B (shaded area between dashed lines), and to the average of ozonesonde measurements (circles). Data from Gregory et al. [this issue] and Browell et al. [this issue]. are rather different than in the remote marine troposphere [Fishman et al.; 1979; Logan et al., 1981; Liu et al., 1983]. Production of $\mathrm{RO}_{2}$ radicals plays a central role over the forest. Over the oceans, the key branch involves competition for $\mathrm{HO}_{2}$ between $\mathrm{O}_{3}$ and $\mathrm{NO}$, and the $\mathrm{NO}$ crossover concentration for $\mathrm{O}_{3}$ production is higher, about 10 ppt [Fishman et al., 1979; Chameides et al., 1987].

A major uncertainty in our analysis is the lack of kinetic data for reactions of $\mathrm{RO}_{2}$ radicals. As shown in Table 12, $\mathrm{C}_{5}$ hydroxy- $\mathrm{RO}_{2}$, radicals produced from isoprene oxidation account for most of the $\mathrm{RO}_{2}$ pool in the model. We investigated the sensitivity of $\mathrm{O}_{3}$ production to the reactivities of $\mathrm{RO}_{2}$ radicals by conducting a series of test simulations where the reaction rates of $>\mathbf{C}_{\mathbf{i}}$ $\mathrm{RO}_{2}$ radicals with $\mathrm{HO}_{2}, \mathrm{NO}$, and $\mathrm{NO}_{2}$ were taken to be (1) zero, (2) 10 times the value in the standard simulation: Results are summarized in Table 13. We find that photochemical loss of $\mathrm{O}_{3}$ in the upper PBL at noon is remarkably insensitive to such variations in the kinetics of the $\mathrm{RO}_{2}$ reactions. Ozone loss rates range from 91 ppt $h^{-1}$ in the simulation with no $\mathrm{RCO}_{3}+\mathrm{NO}_{2}$ reactions to 236 ppt $h^{-1}$ in the simulation with no $\mathrm{RO}_{2}+\mathrm{HO}_{2}$ reactions. This insensitivity is due in part to the inefficiency of odd hydrogen cycling at low $\mathrm{NO}_{x}$ concentrations (section 7), and in part to feedbacks between $\mathrm{RO}_{2}$ and $\mathrm{NO}_{x}$. For example; increasing the rate of the $\mathrm{RO}_{2}+\mathrm{HO}_{2}$ reactions actually reduces photochemical loss because the depletion of $\mathrm{RCO}_{3}$ radicals allows higher concentrations of $\mathrm{NO}_{x}$ to be sustained. Suppressing the $\mathrm{RO}_{2}+\mathrm{HO}_{2}$ reactions depletes $\mathrm{NO}$, raises the $\mathrm{NO}_{2} / \mathrm{NO}$ ratio, and allows $\mathrm{RCO}_{3}$ radicals to accumulate; the $\mathrm{NO}_{2} / \mathrm{RPAN}$ equilibrium is shifted towards RPAN, lowering levels of $\mathrm{NO}_{x}$ and enhancing photochemical loss.

Photochemistry in the lower PBL is somewhat more sensitive to the rates of $\mathrm{RO}_{2}$ reactions, because $\mathrm{NO}_{x}$ levels are higher. For example, if rates for $\mathrm{RO}_{2}+\mathrm{HO}_{2}$ are slow, then the atmosphere shifts from a regime of photochemical production of $\mathrm{O}_{3}$ to photochemical loss (because of $\mathrm{NO}_{x}$ depletion). A similar shift occurs in the

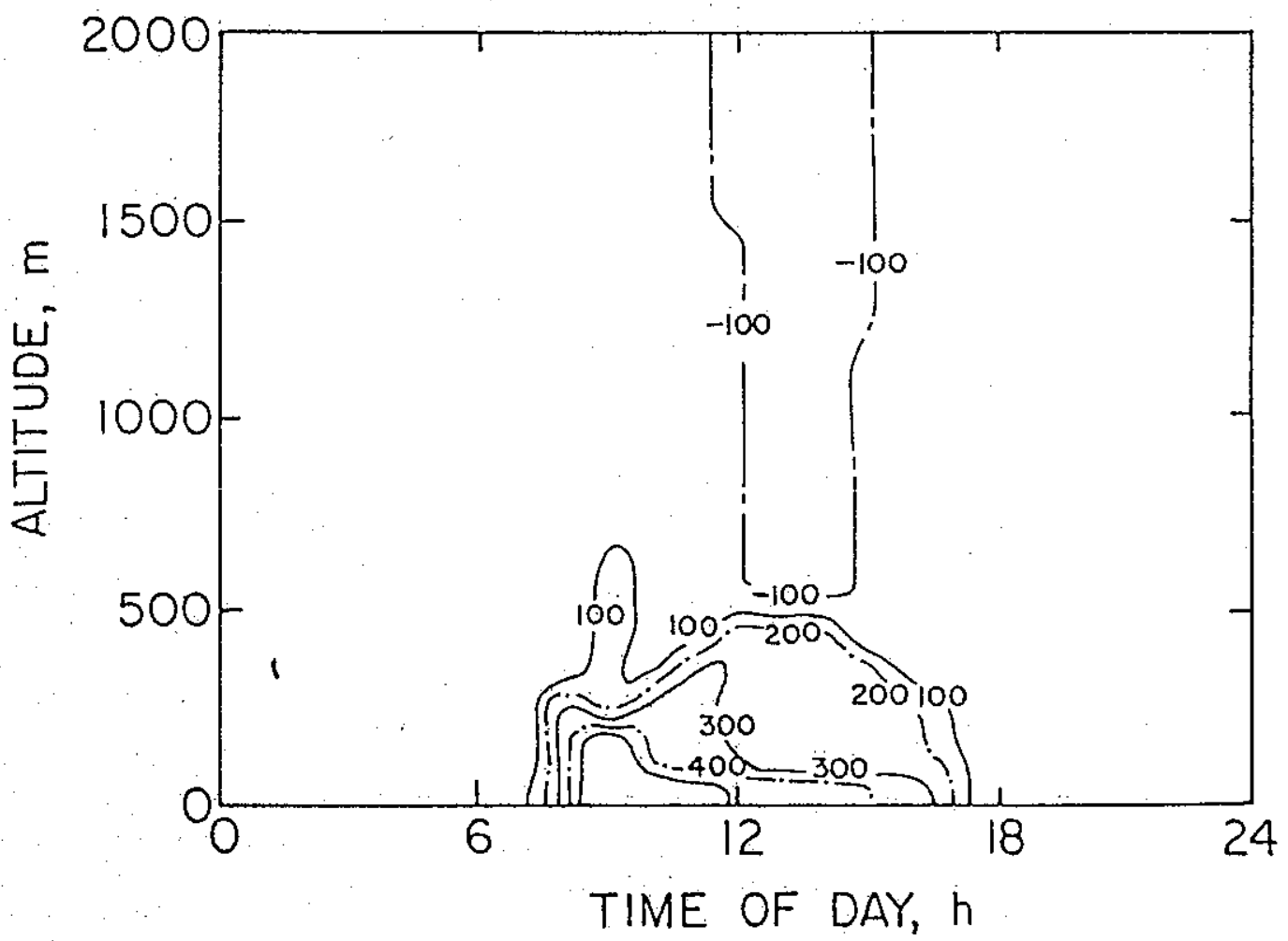

Fig. 14. Simulated photochemical production minus loss rates of $\mathrm{O}_{3}\left(\mathrm{ppt} \mathrm{h}^{-1}\right)$, as a function of altitude and time of day. 
TABLE 12. Maior Contributors to the $\mathrm{RO}_{2}$ Pool Species Total $\mathrm{RO}_{2} \%$ Principal Source

\section{$\mathrm{CH}_{2} \mathrm{C}\left(\mathrm{CH}_{3}\right) \mathrm{CH}\left(\mathrm{OOO}_{0}\right) \mathrm{CH}_{2} \mathrm{OH}$ \\ $\mathrm{CH}_{2} \mathrm{CHC}\left(\mathrm{CH}_{3}\right)(\mathrm{OO} \bullet) \mathrm{CH}_{2} \mathrm{OH}$ $\mathrm{CH}_{2} \mathrm{C}\left(\mathrm{CH}_{3}\right) \mathrm{CH}(\mathrm{OH}) \mathrm{CH}_{2} \mathrm{OO}$. $\mathrm{CH}_{2} \mathrm{CHC}\left(\mathrm{CH}_{3}\right)(\mathrm{OH}) \mathrm{CH}_{2} \mathrm{OO}$}

$$
\mathrm{CH}_{3} \mathrm{OO}
$$

$\mathrm{CH}_{3} \mathrm{C}(\mathrm{O}) \mathrm{OO}$

$\mathrm{CH}_{3} \mathrm{C}(\mathrm{O}) \mathrm{CH}(\mathrm{OO}) \mathrm{CH}_{2} \mathrm{OH}$ $\mathrm{CH}_{3} \mathrm{C}(\mathrm{O}) \mathrm{CH}(\mathrm{OH}) \mathrm{CH}_{2} \mathrm{OO}$.

\section{$\mathrm{CH}_{2} \mathrm{CCH}_{3} \mathrm{C}(\mathrm{O}) \mathrm{OO}$. $\mathrm{CH}_{2}(\mathrm{OH}) \mathrm{CCH}_{3}(\mathrm{OO} \bullet) \mathrm{CHO}$ $\mathrm{CH}_{2} \mathrm{C}(\mathrm{OO}+) \mathrm{C}(\mathrm{OH})\left(\mathrm{CH}_{3}\right) \mathrm{CHO}$ $\mathrm{CH}_{2} \mathrm{C}\left(\mathrm{CH}_{3}\right) \mathrm{OO}$}

$$
\mathrm{CH}_{3} \mathrm{CH}_{2} \mathrm{OO}
$$

Miscellaneous Total

$\begin{array}{ll}26.4 & \text { Isoprene + OH } \\ 26.4 & \text { Isoprene + OH } \\ 11.3 & \text { Isoprene + OH } \\ 11.3 & \text { Isoprene + OH }\end{array}$

$8.4 \mathrm{CH}_{4}+\mathrm{OH}$

\subsection{Methylglyoxal $+h v$}

2.0 Methylvinylketone $+\mathrm{OH}$

1.0 Methylvinylketone $+\mathrm{OH}$

1.8 Methacrolein $+\mathrm{OH}$

1.8 Methacrolein $+\mathrm{OH}$

1.8 Methacrolein $+\mathrm{OH}$

1.3 Methacrolein $+\mathrm{OH}$

$$
1.1 \mathrm{RCO}_{3}+\mathrm{NO}
$$

Model results for grid cell $5(40-500 \mathrm{~m})$ at noon.

absence of $\mathrm{RO}_{2}+\mathrm{NO}$ reactions (because $\mathrm{HO}_{2}$ is then depleted by $\mathrm{RO}_{2}+\mathrm{HO}_{2}$ reactions). In the simulation with no $\mathrm{RO}_{2}+\mathrm{HO}_{2}$ reactions the noontime $\mathrm{NO}$ concentration in the lower PBL is 0.2 ppt, whereas the concentrations observed at that altitude by A. L. Torres and K. R. Hooks (submitted manuscript, 1989) were of order $10 \mathrm{ppt}$. The observation of detectable NO in the lower PBL thus provides indirect evidence for the occurrence of $\mathrm{RO}_{2}+\mathrm{HO}_{2}$ reactions, or at least for a $\mathrm{RO}_{2}$ sink other than reactions with $\mathrm{NO}$ and $\mathrm{NO}_{2}$.

Other possible sinks for $>\mathrm{C}_{1} \mathrm{RO}_{2}$ radicals, which are not considered in the model, include the reactions with $\mathrm{O}_{3}$ and with other $\mathrm{RO}_{2}$ radicals. Atkinson and Lloyd [1984] have argued that the $\mathrm{RO}_{2}+\mathrm{O}_{3}$ reactions should be negligibly slow. The $\mathrm{RO}_{2}+\mathrm{RO}_{2}$ reactions could however be important; this importance is suggested by model results for $\mathrm{CH}_{3} \mathrm{CO}_{3}$, which indicate that the reactions of $\mathrm{CH}_{3} \mathrm{CO}_{3}$ with itself and with $\mathrm{CH}_{3} \mathrm{O}_{2}$ amount together to a sink for $\mathrm{CH}_{3} \mathrm{CO}_{3}$ comparable to reaction with $\mathrm{HO}_{2}$. We did not attempt to consider the sensitivity of model results to the $\mathrm{RO}_{2}+$ $\mathrm{RO}_{2}$ reactions because of the large uncertainty regarding the reaction products. Obviously, our model study points to the need for further laboratory work on these reactions.

\section{SENSITTVITY OF MODEL RESUlTS TO HydROCARBON LEVELS}

Zimmerman et al. [1988] found that several primary NMHCs other than isoprene were present at significant concentrations over the Amazon forest during the dry season. Most of these NMHCs appeared to originate from biomass buming, hence the concentrations in the wet season would probably be much lower. We conducted a sensitivity model simulation assuming NMHC concentrations fixed at the mean values reported by Zimmerman et al. [1988] for unpolluted conditions. These concentrations were 0.37 ppb propane, $0.17 \mathrm{ppb}$ butane, $0.32 \mathrm{ppb}$ pentane, $0.10 \mathrm{ppb}$ higher alkanes, $1.0 \mathrm{ppb}$ ethylene, $0.31 \mathrm{ppb}$ propene, $0.09 \mathrm{ppb}$ benzene, $0.74 \mathrm{ppb}$ toluene, and $0.09 \mathrm{ppb}$ xylene.

Results from the simulation with added NMHCs are compared to the standard simulation in Table 14. Differences are in general small. The addition of NMHCs decreases the concentrations of
TABLE 13. Sensitivity of Model Results to the Rates of $\mathrm{RO}_{2}$ Reaction: molecules $\mathrm{cm}^{-3}$

[NO], $\left[\mathrm{NO}_{x}\right],\left[\mathrm{O}_{3}\right], \overline{\left.\mathrm{RO}_{2}\right]\left[\mathrm{HO}_{2}\right][\mathrm{OH}]}(\mathrm{P}-\mathrm{L}) \mathrm{O}_{3}$ $\mathrm{ppt}$. ppt ppb

$\begin{array}{llllllll}\text { Standard } & 16.4 & 54.6 & 11.3 & 8.2(8) & 2.8(8) & 4.8(5) & +272\end{array}$

$k\left(\mathrm{RO}_{2}+\mathrm{HO}_{2}\right)=0 \quad 0.2 \quad 10.1 \quad 10.02 .4(10) 3.2(8) 3.2(5) \quad-61$

$\begin{array}{lllllll}k\left(\mathrm{RO}_{2}+\mathrm{HO}_{2}\right) \times 10 & 28.5 & 71.4 & 10.7 & 3.2(8) & 1.1(8) & 4.3(5)\end{array} \quad+133$

$\begin{array}{lllllllll}k\left(\mathrm{RO}_{2}+\mathrm{NO}\right)=0 & 36.1 & 63.0 & 9.5 & 1.2(10) & 1.0(7) & 3.0(5) & -151\end{array}$

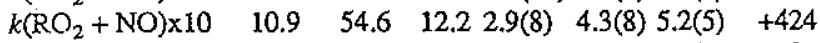

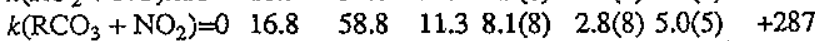

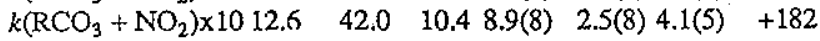

Grid cell $7(1500-2000 \mathrm{~m})$

$\begin{array}{llllllll}k\left(\mathrm{RO}_{2}+\mathrm{HO}_{2}\right)=0 & 0.05 & 1.7 & 14.4 & 2.8(10) & 2.9(8) & 1.7(6) & -236\end{array}$

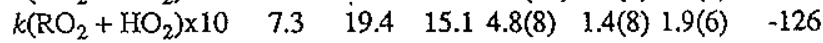

$\begin{array}{llllllll}k\left(\mathrm{RO}_{2}+\mathrm{NO}\right)=0 & 4.5 & 10.2 & 14.1 & 6.7(9) & 5.0(7) & 1.7(6) & -186\end{array}$

$\begin{array}{llllllll}k\left(\mathrm{RO}_{2}+\mathrm{NO}\right) \times 10 & 1.0 & 10.2 & 16.0 & 9.2(8) & 2.9(8) & 1.8(6) & -105\end{array}$

$\begin{array}{llllllll}k\left(\mathrm{RCO}_{3}+\mathrm{NO}_{2}\right)=0 & 4.7 & 17.0 & 15.6 & 1.2(9) & 2.4(8) & 1.9(6) & -91\end{array}$

$\begin{array}{llllllll}k\left(\mathrm{RCO}_{3}+\mathrm{NO}_{2}\right) \times 10 & 0.3 & 1.6 & 17.5 & 2.9(9) & 9.8(7) & 1.6(6) & -224\end{array}$

Results at noon. In the sensitivity simulations the reaction rates for $>\mathrm{C}_{1} \quad \mathrm{RO}_{2}$ radicals are modified to be either zero or 10 times the value in the standard simulation. $(P$ $L) \mathrm{O}_{3}$ is the net photochemical production rate of $\mathrm{O}_{3}$. Read $8.2(8)$ as $8.2 \times 10^{8}$.

$\mathrm{OH}$ and $\mathrm{HO}_{2}$, and increases the concentration of $\mathrm{RO}_{2}$ radicals, as would be expected. The concentration of $\mathrm{NO}_{x}$ decreases by $12 \%$, partly because of the increase in $\mathrm{RCO}_{3}$ concentrations which facilitates the formation of RPAN compounds, and partly because of nighttime reactions of $\mathrm{NO}_{3}$ with cresols and phenols. The decrease in $\mathrm{NO}_{x}$ levels leads to enhanced photochemical loss of $\mathrm{O}_{3}$ in the simulation with added NMHCs, $-0.3 \mathrm{ppb} \mathrm{d}^{-1}$ as compared to $-0.05 \mathrm{pp} \mathrm{d}^{-1}$ in the standard simulation. Photochemical consumption remains nevertheless a small sink for $\mathrm{O}_{3}$ in the PBL compared to deposition.

Computed rates for photochemical production of $\mathrm{CO}$ are remarkably unsensitive to NMHC levels. This result follows largely from the low concentrations of NO, which prevent odd hydrogen cycling. The rate of hydrocarbon oxidation is limited by the supply of $\mathrm{OH}$, which is in turn regulated by $\mathrm{O}_{3}$ photolysis (Figure 12). The production of $\mathrm{CO}$ over the Amazon forest appears therefore to be dependent not on the supply of NMHCs but rather on rates for $\mathrm{O}_{3}$ photolysis, levels of $\mathrm{H}_{2} \mathrm{O}$, and $\mathrm{CO}$ yields from NMHC oxidation. As pointed out in section 6 , the $\mathrm{CO}$ yields are expected to be low because water-soluble hydrocarbon intermediates are removed by wet deposition.

\section{CONCLUSIONS}

The atmospheric composition observed over the Amazon forest during the wet season reflects influences from deposition to the forest canopy, biogenic sources of NO and hydrocarbons, exchange with the free troposphere, and influx from polluted regions. We analyzed the contributions from these various influences to the budgets of chemically reactive species, using a photochemical model for the PBL $(0-2000 \mathrm{~m})$ with detailed simulation of deposition processes in the canopy. Results indicate that only $19 \%$ of $\mathrm{NO}_{x}$ emitted by soil is exported to the PBL on a 24 -hour average basis; the balance is removed by deposition of $\mathrm{NO}_{2}$ to vegetation. The small fraction of $\mathrm{NO}_{x}$ soil emissions exported from the canopy is nevertheless sufficient to account for the NO 
TABLE 14. Sensitivity of Model Results to Hydrocarbon Levels Standard Simulation Simulation With Added NMHCs Molecules $\mathrm{cm}^{-3}$

$\begin{array}{lcc}\mathrm{OH} & 3.5(5) & 2.2(5) \\ \mathrm{HO}_{2} & 8.2(7) & 7.9(7) \\ \mathrm{CH}_{3} \mathrm{CO}_{3} & 1.5(7) & 1.6(7) \\ \mathrm{RO}_{2} & 4.7(8) & 6.5(8)\end{array}$

\section{Parts per Trillion}

$\begin{array}{lcc}\text { NO } & 3.4 & 2.8 \\ \mathrm{NO}_{\mathrm{x}} & 26 & 23 \\ \text { PAN } & 5.2 & 4.3 \\ \text { RPAN } & 12 & 14\end{array}$

\section{Parts per Billion}

$\mathrm{CO}$ 90.5 91.2

Daily mean concentrations in the PBL air column $(30-2000 \mathrm{~m})$. Read 3.5(5) as $3.5 \times 10^{5}$.

levels observed in the PBL, implying that soil emissions regulate the levels of $\mathrm{NO}_{x}$ in the lower atmosphere. Decomposition of PAN transported from the free troposphere provides only a small source of $\mathrm{NO}_{x}$ to the PBL, as compared to soil emission, because mass exchange between the PBL and the free troposphere is relatively slow. Soil emissions of NO can account for only a small fraction of total reactive nitrogen $\left(\mathrm{NO}_{\mathrm{y}}\right)$ observed over the forest, and we speculate that organic nitrates transported from sources outside the Amazon Basin make a large contribution to the $\mathrm{NO}_{\mathrm{y}}$ budget. Ventilation of biogenic $\mathrm{NO}_{x}$ from the PBL to higher altitudes is negligible, indicating that $\mathrm{NO}_{x}$ above $2000 \mathrm{~m}$ must be supplied by a different source, e.g., decomposition of PAN as suggested by Singh et al. [this issue].

Photochemical activity in the atmosphere over the Amazon forest is limited by the low concentrations of $\mathrm{NO}_{x}$. Oxidation of isoprene is slow and yields principally organic peroxides that are removed by wet and dry deposition. The observed enhancements of $\mathrm{CO}$ in the PBL cannot be attributed to oxidation of isoprene or other hydrocarbons and probably result from direct emission of $\mathrm{CO}$ by the forest ecosystem.

Concentrations of $\mathrm{O}_{3}$ in the PBL reflect largely a balance between supply from the free troposphere and removal by deposition to vegetation. Ozone is photochemically produced just above the canopy, and photochemically consumed in the upper PBL; overall, the net effect of photochemistry on $\mathrm{O}_{3}$ levels in the PBL is small. This result contrasts with diry season conditions, when NO concentrations are sufficiently high to provide a vigorous photochemical source of $\mathrm{O}_{3}$ in the PBL.

Acknowledgments. This research was supported by funds from the National Aeronautics and Space Administration (grant NASA NAG1-55) and from the National Science Foundation (grants NSF-ATM 8413153 and NSF-ATM 8858074).

\section{REFERENCES}

Andreae, M.O., et al., Biomass-burning emissions and associated haze layers over Amazonia, J, Geophys. Res., 93 1509-1527, 1988.

Andreae, M.O., R.W. Talbot, H. Berresheim, and K.M. Beecher, Precipitation chemistry in central Amazonia, J. Geophys. Res., this issue (a).
Andreae, M.O., H. Berresheim, H. Bingemer, D.J. Jacob, and R.W. Talbot, The atmospheric sulfur cycle over the Amazon Basin, 2, Wet season, $J$. Geophys. Res., this issue (b).

Atkinson, R., and A.L. Lloyd, Evaluation of kinetic and mechanistic data for modeling of photochemical smog, J. Phys. Chem. Ref. Data, 13, 315-444, 1984.

Bakwin, P.S., S.C. Wofsy, and S.-M. Fan, Measurements of reactive nitrogen oxides $\left(\mathrm{NO}_{\mathrm{y}}\right.$ ) within and above a tropical forest canopy in the wet season, J. Geophys. Res., this issue (a).

Bakwin, P.S., S.C. Wofsy, S.-M. Fan, M. Keller, S. Trumbore, and J. M. da Costa, Emission of nitric oxide (NO) from tropical forest soils and exchange of NO between the forest canopy and atmospheric boundary layers, J. Geophys. Res., this issue (b).

Browell, E. V., G. L. Gregory, R. C. Harriss, and V. W. J. H. Kirchhoff, Ozone and aerosol distributions over the Amazon Basin during the wet season, J. Geophys. Res., this issue.

Browell, E.V., G.L. Gregory, R.C. Harriss, and V.W.J.H. Kirchhoff, Tropospheric ozone and aerosol distributions across the Amazon Basin, $J$. Geophys. Res., 93, 1431-1451, 1988.

Chameides, W.L., D.D. Davis, M.O. Rodgers, J. Bradshaw, S. Sandholm, G. Sachse, G. Hill, G. Gregory, and R. Rasmussen, Net ozone photochemical production over the eastem and central North Pacific as inferred from GTE/CITE 1 observations during dall 1983, J. Geophys. Res., 92, 2131-2152, 1987.

Chatfield, R.B., and A.C. Delany, Convection links biomass buming to increased tropical ozone: However, models will typically overpredict $\mathrm{O}_{3}$, J. Geophys. Res., in press, 1990.

Crutzen, P.J., The role of $\mathrm{NO}$ and $\mathrm{NO}_{2}$ in the chemistry of the troposphere and stratosphere, Annu. Rev. Earth Planet. Sci., 7, 443-472, 1979.

Crutzen, P.J., A.C. Delany, J. Greenberg, P. Haagenson, L. Heidt, R. Lueb, W. Pollock, W. Seiler, A. Wartburg, and P. Zimmerman, Tropospheric chemical composition measurements in Brazil during the dry season, $J$. Atmos. Chem., 2, 233-256, 1985.

Dalluge, R., R.A. Rasmussen, and M.A.K. Khalil, Isoprene fluxes from ABLE, Eos Trans. AGU, 68, 1220, 1987.

Fan, S.-M., S.C. Wofsy, P.S. Bakwin, and D.J. Jacob, Atmospherebiosphere exchange of $\mathrm{CO}_{2}$ and $\mathrm{O}_{3}$ in the central Amazon forest, J. Geophys. Res., this issue.

Fishman, J., S. Solomon, and P.J. Crutzen, Observational and theoretical evidence in support of a significant in-situ photochemical source of tropospheric ozone, Tellus, 31, 432-446, 1979.

Fitzjarrald, D.R., and K.E. Moore, Mechanisms of nocturnal exchange between the rain forest and the atmosphere, J. Geophys. Res., this issue.

Fitzjarrald, D.R., B.L. Stomwind, G. Fisch, and O.M.R. Cabral, Turbulent transport observed just above the Amazon forest, J. Geophys. Res., 93 1551-1563, 1988.

Fitzjarrald, D.R., K.E. Moore, O.M.R. Cabral, J. Scolar, A.O. Manzi, and L.D. de Abreu Sa, Daytime turbulent exchange between the Amazon forest and the atmosphere, J. Geophys. Res., this issue.

Gregory, G.L., E.V. Browell, and L.S. Warren, Boundary layer ozone: an aitome survey across the Amazon Basin, J. Geophys. Res., 93, 1452$1468,1988$.

Gregory, G.L., E. Browell, L.S. Warren, and C.H. Hudgins, Amazon Basin ozone and aerosol: wet season observations, J. Geophys. Res., this issue.

Harriss, R.C., et al., The Amazon Boundary Layer Experiment (ABLE 2B): Wet season 1987, J. Geophys. Res., this issue (a).

Harriss, R.C., G.W. Sachse, G.F. Hill, G.L. Gregory, and J. Fishman, Carbon monoxide over the Amazon Basin during the 1987 wet season, submitued to J. Geophys. Res., this issue (b).

Jacob, D.J., and S.C. Wofsy, Photochemistry of biogenic emissions over the Amazon forest, J. Geophys. Res., 93, 1477-1486, 1988.

$\mathrm{J}_{\mathrm{acob}}$ D.J., and P.S. Bakwin, Cycling of $\mathrm{NO}_{x}$ in tropical forest canopies and its implications for the global source of biogenic $\mathrm{NO}_{x}$ to the atmosphere, in Microbial Production and Consumption of Greenhouse Gases, edited by W.B. Whitman, American Society of Microbiology, Washington, D.C., in press, 1990. 
Jones, H.G., Plants and Microclimate, Cambridge University Press, New York, 1983.

Kasting, J.F., and H.B. Singh, Nonmethane hydrocatbons in the troposphere: impact on the odd hydrogen and odd nitrogen chemistry, J. Geophys. Res., 91, 13,239-13,256, 1986.

Keller, M., D.J. Jacob, S.C. Wofsy, and R.C. Harriss, Effects of tropical deforestation on global and regional atmospheric chemistry, Clim. Change, in press, 1990.

Kirchhoff, V.W.J.H., and E.V. Marinho, Surface carbon monoxide measurements in Amazonia, J. Geophys. Res., this issue.

Kirchhoff, V.W.J.H., A.W. Setzer, and M.C. Pereira, Biomass buming in Amazonia: Seasonal effects on atmospheric $\mathrm{O}_{3}$ and $\mathrm{CO}$, Geophys. Res. Lett., 16, 469-472, 1989.

Kirchhoff, V.W.J.H., I.M.O. da Silva, and E.V. Browell, Ozone measurements in Amazonia: Dry season vs. wet season, J. Geophys. Res., this issue.

Kousky, V.E., and M.T. Kagano, A climatological study of the tropospheric circulation over the Amazon region, Acta Amazonica, 11,743-758, 1981.

Lamb, B., A. Guenther, D. Gay, and H. Westberg, A national inventory of biogenic hydrocarbon emissions, Atmos. Environ., 21, 1695-1705, 1987.

Lin, X., M. Trainer, and S.C. Liu, On the nonlinearity of tropospheric ozone production, J. Geophys. Res., 93, 15,879-15,888, 1988.

Liu, S.C., M. McFarland, D. Kley, O. Zafiriou, and B. Huebert, Tropospheric $\mathrm{NO}_{x}$ and $\mathrm{O}_{3}$ budgets in the equatorial Pacific, J. Geophys. Res., $88,1360-1368,1983$.

Lloyd, A.C., R. Atkinson, F.W. Lumann, and B. Nitta, Modeling potential ozone impacts from natural hydrocarbons, I, Development and testing of a chemical mechanism for the $\mathrm{NO}_{x}$-air photooxidations of isoprene and $\alpha$-pinene under ambient conditions, Atmos. Environ., 17, 1931-1950, 1983.

Logan, J.A., M.J. Prather, S.C. Wofsy, and M.B. McElroy, Tropospheric chemistry: a global perspective, J. Geophys. Res., 86, 7210-7254, 1981.

Lowe, D.C., and U. Schmidt, Formaldehyde measurements in the nonurban atmosphere, J. Geophys. Res., 88, 10,844-10,858, 1983.

Lurmann, F.W., A.C. Lloyd, and R. Atkinson, A chemical mechanism for use in long-range transport/acid deposition computer modeling, J. Geophys. Res., 91, 10,905-10,936, 1986.

Menzel, W.P., T. J. Schmit, and D. P. Wylie, Cloud characteristics over central Amazonia during GTE/ABLE 2B derived from multispectral visible and infrared spin scan radiometer atmospheric sound observations, J. Geophys. Res., this issue.

Meyers, T.P., and D.D. Baldocchi, A comparison of models for deriving dry deposition fluxes of $\mathrm{O}_{3}$ and $\mathrm{SO}_{2}$ to a forest canopy, Tellus, $40 \mathrm{~B}$, 270-284, 1988.

Moortgaat, G.K., B. Veyret, and R. Lesclaux, Absorption spectrum and kinetics of reactions of the acetylperoxy radical, J. Phys. Chem., 93, 2362-2368, 1989a.

Moortgaat, G.K., B. Veyret, and R. Lesclaux, Kinetics of the reaction of $\mathrm{HO}_{2}$ with $\mathrm{CH}_{3} \mathrm{C}(\mathrm{O}) \mathrm{O}_{2}$ in the temperature range $253-368 \mathrm{~K}$, Chem. Phys. Lett., 160, 443-447, 1989 b.

Neitzert, V., and W. Seiler, Measurement of formaldehyde in clean air, Geophys. Res. Lett., 8, 79-82, 1981.

Parsons, T.R., M. Takahashi, and B. Hargrave, Biological Oceanographic Processes, 2nd ed., pp. 73-74, Pergamon Press, New York, 1977.

Rasmussen, R.A., and M.A.K. Khalil, Isoprene over the Amazon Basin, $J$. Geophys. Res., 93, 1417-1421, 1988.

Richtmeyer, R.D., Difference Methods for Initial Value Problems, p. 101, Wiley-Interscience, New York, 1957.
Roberts, J., O.M.R. Cabral, and L.F. De Aguiar, Stomatal and boundar. layer conductances measured in an Amazonian Terra Firme rain forest, $j$. Appl. Ecol., 27, 336-353, 1990.

Scala, J.R., et al., Cloud draft structure and trace gas transport, J. Geophys. Res., this issue.

Seiler, W. The influence of the biosphere on the atmospheric $\mathrm{CO}$ and $\mathrm{H}_{2}$ cycles, in Environmental Biogeochemistry and Geomicrobiology, vol. 3, edited by W.E. Krumbein, pp. 773-810, Ann Arbor Science Publishers, Ann Arbor, Michigan, 1978.

Shreffler, J.H., Factors affecting dry deposition of $\mathrm{SO}_{2}$ on forests and grasslands, Atmos. Environ., 12, 1497-1503, 1978.

Shuttleworth, W.J., et al., Observations of radiation exchange above and below Amazonian forest, Q. J. R. Meteorol. Soc., 110, 1163-1169, 1984.

Singh, H.B., Reactive nitrogen in the troposphere, Environ. Sci. Technol. $21,320-327,1987$.

Singh, H.B., D. Herlth, D. O’Hara, L. Salas, A. L. Torres, G. L. Gregory, G. W. Sachse, and J. F. Kasting, Atmospheric peroxyacetyl nitrate measurements over the Brazilian Amazon Basin during the wet season: Relationship with nitrogen oxides and ozone, J. Geophys. Res., this issue.

Snider, J.R., and G.A. Dawson, Tropospheric light alcohols, carbonyls, and acetonitrile: Concentrations in the southwestem United States and Henry's law data, J. Geophys. Res., 90, 3797-3805, 1985.

Talbot, R.W., M.O. Andreae, H. Berresheim, P. Antaxo, M. Garstang, R.C. Harriss, K.M. Beecher, and S.M. Li, Aerosol chemistry during the wet season in central Amazonia: The influence of long-range transport, $J$. Geophys. Res., this issue (a).

Talbot, R.W., M.O. Andreae, H. Berresheim, D.J. Jacob, and K.M. Beecher, Sources and sinks of formic, acetic, and pyruvic acids over central Amazonia 2, Wet season, J. Geophys. Res., this issue (b).

Tingey, D.T., M. Manning, L.C. Grothaus, and W.F. Bums, The influence of light and temperature on isoprene emission rates from live aak, $P$ hysiol. Plant., 47, 112-118, 1979.

Torres, A.L., and H. Buchan, Tropospheric nitric oxide measurements over the Amazon Basin, J. Geophys. Res., 93, 1396-1406, 1988.

Trumbore, S.E., M. Keller, S.C. Wofsy, and J.M. da Costa, Measurements of soil and canopy exchange rates in the Amazon rain forest using ${ }^{222} \mathrm{Rn}$, J. Geophys. Res., this issue.

Verstraete, M.M., Radiation transfer in plant canopies: transmission of direct solar radiation and the role of leaf orientation, J. Geophys. Res., 92, 10,985-10,995, 1987.

Wesely, M.L., Improved parameterizations for surface resistance to gaseous dry deposition in regional-scale, numerical models, Atmos. Environ., 23, 1293-1304, 1989.

Zimmerman, P.R., R.B. Chatfield, J. Fishman, P.J. Crutzen, and P.L. Hanst, Estimates on the production of $\mathrm{CO}$ and $\mathrm{H}_{2}$ from the oxidation of hydrocarbon emissions from vegetation, Geophys. Res. Lett., S, 679-682, 1978.

Zimmerman, P.R., J.P Greenberg, and C.E. Westberg, Measurements of atmospheric hydrocartons and biogenic emission fluxes in the Amazon boundary layer, J. Geophys. Res., 93, 1407-1416, 1988.

D. J. Jacob and S. C. Wofsy, Department of Earth and Planetary Sciences and Division of Applied Sciences, Harvard University, Cambridge, MA 02138.

(Received June 26, 1989; revised December 18, 1989; accepted December 19, 1989.) 